\title{
Observation and Simulation of Wind Speed and Wind Power Density over Bac Lieu Region
}

\author{
Hiep Van Nguyen $\mathbb{D}^{1},{ }^{1}$ Pham Xuan Thanh ${ }^{D},{ }^{1}$ Nguyen Duc Nam, ${ }^{1}$ Nguyen Xuan Anh $\mathbb{D}^{1},{ }^{1}$ \\ Pham Le Khuong, ${ }^{1,2}$ Hoang Hai Son, ${ }^{1,2}$ Nguyen Tien Manh, ${ }^{1}$ and Pham Chi Cong ${ }^{3}$ \\ ${ }^{1}$ Institute of Geophysics (IGP), Vietnam Academy of Science and Technology (VAST), Hanoi, Vietnam \\ ${ }^{2}$ Graduate University of Sciences and Technology (GUST), Vietnam Academy of Science and Technology (VAST), Hanoi, Vietnam \\ ${ }^{3}$ Vietnam Research Institute of Electronics, Informatics and Automation (VIELINA), Hanoi, Vietnam \\ Correspondence should be addressed to Hiep Van Nguyen; hiepwork@gmail.com
}

Received 4 March 2020; Revised 1 March 2021; Accepted 26 April 2021; Published 17 May 2021

Academic Editor: Alastair Williams

Copyright (c) 2021 Hiep Van Nguyen et al. This is an open access article distributed under the Creative Commons Attribution License, which permits unrestricted use, distribution, and reproduction in any medium, provided the original work is properly cited.

\begin{abstract}
In this study, the WRF (Weather Research and Forecasting) model was used to simulate and investigate diurnal and annual variations of wind speed and wind power density over Southern Vietnam at 2-km horizontal resolution for two years (2016 and 2017). The model initial and boundary conditions are from the National Centers for Environmental Prediction (NCEP) Final Analyses (FNL). Observation data for two years at $20 \mathrm{~m}$ height at Bac Lieu station were used for model bias correction and investigating diurnal and annual variation of wind speeds. The results show that the WRF model overestimates wind speeds. After bias correction, the model reasonably well simulates wind speeds over the research area. Wind speed and wind power density show much higher values at levels of 50-200 m above ground levels than near ground $(20 \mathrm{~m})$ level and significantly higher near the coastal regions than inland. Wind speed has significant annual and diurnal cycles. Both annual and diurnal cycles of wind speeds were well simulated by the model. Wind speed is much stronger during daytime than at nighttime. Low-level wind speed reaches the maximum at about $14 \mathrm{LT}$ to $15 \mathrm{LT}$ when the vertical momentum mixing is highly active. Wind speeds over the eastern coastal region of Southern Vietnam are much stronger in winter than in summer due to two main reasons, including (1) stronger largescale wind speed in winter than in summer and (2) funnel effect creating a local maximum wind speed over the nearshore ocean which then transports high-momentum air inland in winter.
\end{abstract}

\section{Introduction}

Wind energy is an increasingly important contribution to the market of the world's electricity. According to the report of the International Renewable Energy Agency (IRENA) in 2018, wind energy is the second most important renewable source of electric power in the world, only after hydropower [1]. In the last ten years, the wind power energy production has increased more than 3.8 times (from $150 \mathrm{GW}$ in 2009 to $564 \mathrm{GW}$ in 2018) with an annual growth rate of about $50 \mathrm{GW} /$ year [1].

To exploit wind energy, the most important step is to assess the wind energy potential, which is expressed under a type of kinetic energy. The total annual kinetic energy of air movement in the atmosphere is around $3 \times 10^{15} \mathrm{kWh}$, which can be equivalent to $0.2 \%$ of the solar energy reaching the Earth. The usable potential of wind energy is evaluated to be $30 \times 10^{12} \mathrm{kWh} /$ year [2]. The wind energy potential has been accessed over many regions of the world, both inland and oversea [3-13]. To assess the potential of wind energy in a region, it is essential to investigate the wind speed properties in the region. The wind speed at a particular location can be best determined from measurements by anemometers placed on meteorological towers. Due to the high cost of wind measurement, simulated winds from mesoscale numerical models are also utilized to assess the wind power potential over large areas [10, 14-20].

Since Vietnam has more than $3,000 \mathrm{~km}$ of coastline, there are favorable conditions for wind power development. 
The summer is predominated by southwest winds, whereas the winter is governed by the northeast wind. In 2012, the first wind power plant was installed in Binh Thuan. By the end of 2018, the total energy of wind power plants installed in Vietnam reached approximately $200 \mathrm{MW}$. As stated in the plan of national electricity development, Vietnam will install a total capacity of $6,000 \mathrm{MW}$ of wind power, which satisfies approximately $2.1 \%$ of total energy demand by 2030 [21].

Luu et al. [22] observed wind speeds at $40 \mathrm{~m}$ height from May 1998 to April 2000 to estimate wind power density in Quy Nhon, Binh Dinh, Vietnam, to state that the annual mean wind speed is about $5.5 \mathrm{~m} \mathrm{~s}^{-1}$ and the wind power density is about $188 \mathrm{~W} \mathrm{~m}^{-2}$ [22]. Under the sponsorship of the World Bank, the True Wind Solutions (TWS) Company constructed wind speed maps at $30 \mathrm{~m}$ and $65 \mathrm{~m}$ height for Vietnam [23]. The wind speed map is based on the outputs of the MesoMap model and wind data observed at $40 \mathrm{~m}$ height at Quy Nhon, Vietnam, and other stations at $10 \mathrm{~m}$ height from the Hydrometeorology network system in Vietnam. The results indicated that Vietnam has high potential wind energy, with more than $39 \%$ of the country area having an annual mean wind speed of more than $6 \mathrm{~m} \mathrm{~s}^{-1}$ at $65-\mathrm{m}$ height, equivalent to wind energy of 512 GW [23]. Nguyen [11] used the wind data provided by the World Bank to assess the wind energy potential in Vietnam. The author showed that Vietnam has good potential wind energy with about $31,000 \mathrm{~km}^{2}$ of inland area that can be available for exploiting wind energy, of which there is about $865 \mathrm{~km}^{2}$ of high potential wind energy at the cost of 6 US cent per kWh. The total wind power production of the high potential area alone is about $3572 \mathrm{MW}$ [11].

In 2011, under the sponsorship of the World Bank, the AWS TruePower company created an updated wind resource Atlas of Vietnam [24]. The main goal of the project was to update the previous wind energy resource Atlas of Southeast Asia (2001) using the latest available wind measurements. A set of wind energy maps constructed for 60, 80, and $100 \mathrm{~m}$ height shows that the areas of high potential wind energy are concentrated mainly in the coastal areas of the southern provinces, between Ho Chi Minh City and Khanh Hoa province. Under the sponsorship of the World Bank, the University of Technology of Denmark collaborated with other organizations to develop a global wind Atlas (wind speed and wind power density map) at 50, 100 and $200 \mathrm{~m}$ level in 2018. The set of maps was created by running the WRF model at a resolution of $3 \mathrm{~km}$ and then was downscaled to $250 \mathrm{~m}$ resolution using Wind Atlas Analysis and Application Program (WAsP) microscale model. The global wind Atlas covers entire mainland and $30 \mathrm{~km}$ shoreline [1]. Although the maps provide overall pictures of wind energy resources for the region of Vietnam, to exploit wind energy or evaluate wind energy potential at a specific location of Vietnam, further analyses based on more intensive observation and higher resolution dynamical models should be conducted.

The southern region of Vietnam is embedded in the Southeast Asia monsoon region. Wind is characterized by monsoon circulation with two seasons: the summer monsoon from May to October and the winter monsoon from November to April $[25,26]$. The summer monsoon is onset when the trade winds from Southern Hemisphere flow through the equator and change direction to be southwesterly [25, 27]. The summer monsoon is strongest in July and August. In winter, the northeast monsoon is dominated $[25,27]$. The winter monsoon is strongest in December and January. In addition to the dominated monsoon circulation, in the southeastern coastal areas, including Bac Lieu, local wind regimes such as land-sea breezes are also observed, especially during weak monsoon days. In Vietnam, land-sea breezes blow in the coastal region and have a significant influence to $5-10 \mathrm{~km}$ inland [27].

This study firstly verifies a high-resolution WRF model on simulating wind speeds and wind power density over the Southern Vietnam region. A wind speed adjustment scheme was constructed to adjust WRF-simulated wind speed with observation to reduce systematic overestimating wind speed of the model. Secondly, adjusted wind speeds from the high $(2 \mathrm{~km})$ resolution simulation are used to investigate the spatial distribution of wind speed and wind power density over Southern Vietnam. Finally, observed and simulated wind speeds were used to investigate the diurnal and annual cycle of wind speeds in the region. The next section of the article will present data and methodology. The main results are shown in Section 3. A summary is given in Section 4.

\section{Data and Methodology}

2.1. Model Configuration. In this study, a nonhydrostatic, three-dimensional primitive equation model, the Weather Research and Forecasting (WRF) model [28], version 3.7, was used to simulate the meteorological fields over Bac Lieu and Southern Vietnam regions. Data from the National Centers for Environmental Prediction (NCEP) Final Analyses (FNL) at one-degree horizontal resolution were used to initialize the WRF model.

The WRF model was configured with four nested domains in two-way nesting mode. The horizontal resolutions are $54 \mathrm{~km}$, $18 \mathrm{~km}, 6 \mathrm{~km}$, and $2 \mathrm{~km}$, and horizontal dimensions are $100 \times 61$, $154 \times 145,163 \times 217$, and $127 \times 133$, respectively (Figure 1 ). There are 38 vertical levels from the surface to $50 \mathrm{hPa}$ level. The physical parameterization options (e.g., convective scheme and cloud microphysics) in WRF are represented in Table 1. The physical model configurations were selected based on previous studies [14, 28-34]. The terrain height, land use, and soil type data for the lower boundary conditions of the model are from the USGS global dataset with 24 categories of vegetation data and 17 categories of soil type data. The highest resolution of the dataset is $30 \mathrm{~s}$ of longitude (or about $1 \mathrm{~km}$ ). Model is initialized every day at $00 Z$ and run for 36 hours from January $1^{\text {st }} 2016$ to December $31^{\text {st }}$ 2017. A total of 731 high-resolution, 36-hour model runs are conducted. To avoid the effect of model spin-up time on simulated data quality, the first 12-hour data are not used. Data from $13^{\text {th }}$ to $36^{\text {th }}$ hour are used for verification and construction of wind speed and wind energy maps.

2.2. Data. Wind data measured at $20 \mathrm{~m}$ height at the Atmospheric Physics Bac Lieu station $\left(9.299^{\circ} \mathrm{N}, 105.711^{\circ} \mathrm{E}\right)$ were used in this work (Figure 2) for verification and 


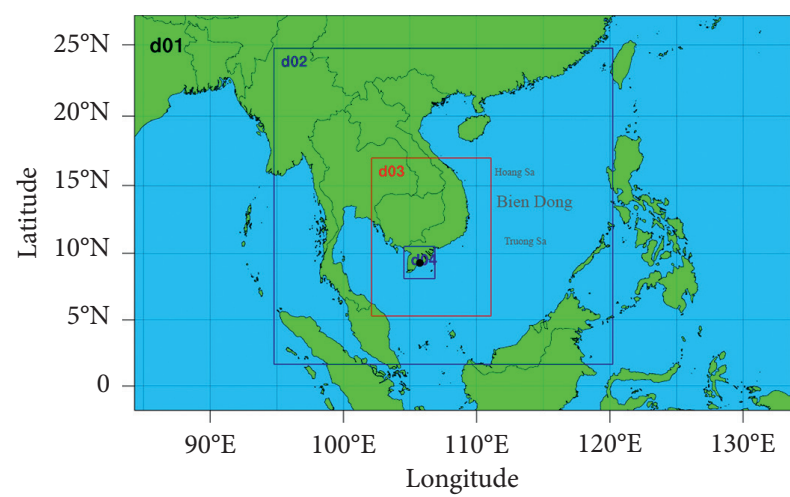

Figure 1: The four nested domains employed in this work with horizontal resolution of $54 \mathrm{~km}(\mathrm{~d} 01), 18 \mathrm{~km}(\mathrm{~d} 02), 6 \mathrm{~km}(\mathrm{~d} 03)$, and $2 \mathrm{~km}$ (d04), respectively.

TABLE 1: Physic configurations for simulation in WRF.

\begin{tabular}{lcc}
\hline Model physics & Scheme & Reference \\
\hline Surface layer & The Monin-Obukhov & {$[28]$} \\
Microphysics & similarity & {$[29]$} \\
Short-wave radiation & Dudhia & {$[30]$} \\
Long-wave radiation & Rapid Radiative Transfer & {$[31]$} \\
$\begin{array}{l}\text { Planetary boundary } \\
\text { layer }\end{array}$ & Model (RRTM) & \\
$\begin{array}{l}\text { Convective } \\
\text { parameterization }\end{array}$ & The Yonsei University & {$[28]$} \\
\hline
\end{tabular}

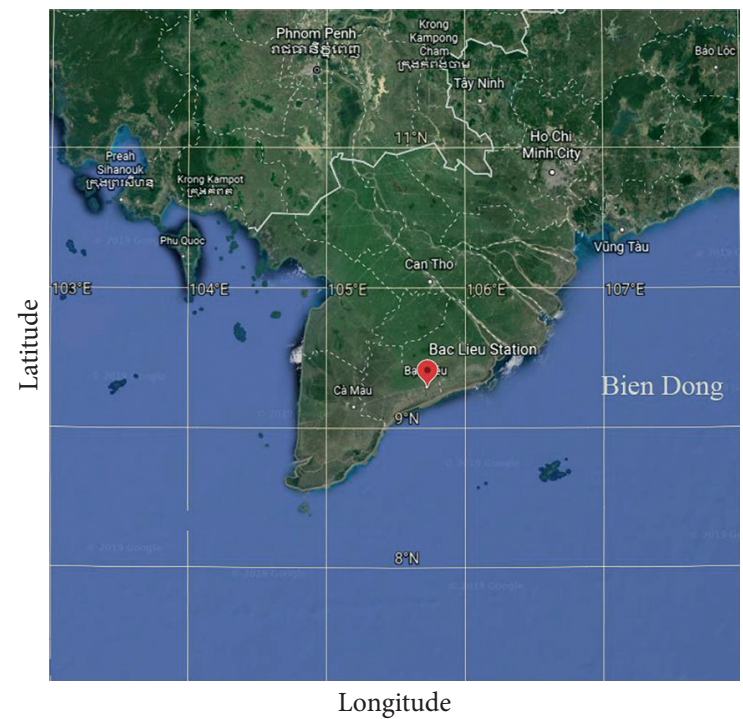

Figure 2: Location of Bac Lieu station.

adjustment of simulated wind speed and investigating the diurnal and annual variation of wind speed. Bac Lieu station location is about $10 \mathrm{~km}$ from the sea. Rice fields are within a radius of $200 \mathrm{~m}$ from the station. The anemometer is provided by Davis Instruments Company, USA. The anemometer model is the Davis 6163 Wireless Vantage Pro2 Plus with a wind speed measure range of $1.0-67.0 \mathrm{~m} \mathrm{~s}^{-1}$ and an accuracy of $1 \mathrm{~m} \mathrm{~s}^{-1}$ (or $5 \%$, whichever is greater). The anemometer has been calibrated by the Inspection Center of the Ministry of Natural Resources and Environment. The wind speed at $20 \mathrm{~m}$ level from surface is measured at a temporal resolution of $1 \mathrm{~min}$ for a two-year period from January 2016 to December 2017. The one-minute data are used to compute hourly data for comparison with model simulation.

Two years (January 2016 to December 2017) of highresolution $(2 \mathrm{~km}) \mathrm{WRF}$ data and observation are used to compute error statistics and investigate the diurnal and annual variation of wind speeds at Bac Lieu station and over the research area. Simulated data after adjustment are also used to construct maps of wind speeds and wind energy at $10,20,50,100$, and $200 \mathrm{~m}$ height above ground. The grid FNL data are used as model input. The FNL data are also used for model verification and analysis of wind speed distribution on the grid.

2.3. Wind Speed Adjustment Method. The model wind speeds are adjusted to remove the model systematic bias using the following empirical function:

$$
U_{\text {mod }}^{\text {adj }}=U_{\text {mod }}-\alpha \text { Bias, }
$$

where $\mathrm{U}$ is the wind speed and Bias is the model bias of wind speed at $20 \mathrm{~m}$ level at Bac Lieu station. Alpha is an empirical parameter for wind speed adjustment at a grid point to make sure that the wind speed is not negative after adjustment. Without $\alpha$ in equation (1), the simulated wind speed less than the Bias value will be less than zero, which is not valid for wind speed. The $\alpha$ parameter is to make sure that wind speed is less reduced by adjustment to avoid negative value after adjustment. Alpha is calculated as follows:

$$
\begin{aligned}
\text { Bias } & =\bar{U}_{\text {mod }}^{\text {sta }}-\bar{U}_{\text {obs }}^{\text {sta }} \\
\alpha_{1} & =\exp \left[-\left(\frac{2 \text { Bias }-U_{\text {mod }}}{\beta U_{\text {mod }}}\right)^{2}\right], \\
\alpha_{2} & =\sqrt{\frac{U_{\text {mod }}}{2 B i a s}} ; \\
\beta & =2.8, \\
\alpha & = \begin{cases}\frac{\alpha_{1}+\alpha_{2}}{2}, & \text { if } U_{\text {mod }} \leq 2 \text { Bias, } \\
1, & \text { if } U_{\text {mod }}>2 \text { Bias, }\end{cases}
\end{aligned}
$$

The values of $\alpha$ as a function of wind speeds are shown in Figure 3(a). Based on the value of alpha, wind speed larger than $4 \mathrm{~m} \mathrm{~s}^{-1}$ is fully reduced by the model bias value. The small wind speed is less changed with the adjustment.

The scatter plot of model vs. observed sorted wind speed (Figure 3(b)) shows that after bias correction, wind speeds were well adjusted. The model bias was mostly removed. It can be seen that wind speeds greater than $4 \mathrm{~m} \mathrm{~s}^{-1}$ also have similar values of systematic errors to those at lower wind speeds. Only two extreme values of wind speed higher than 


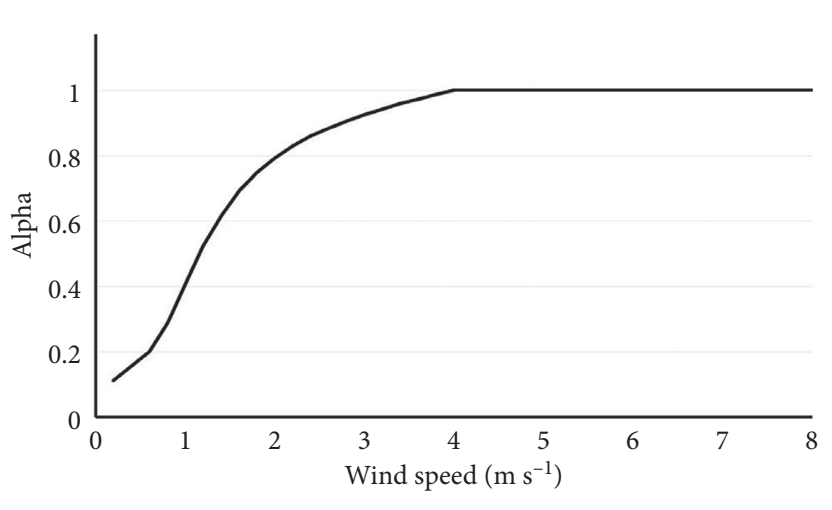

(a)

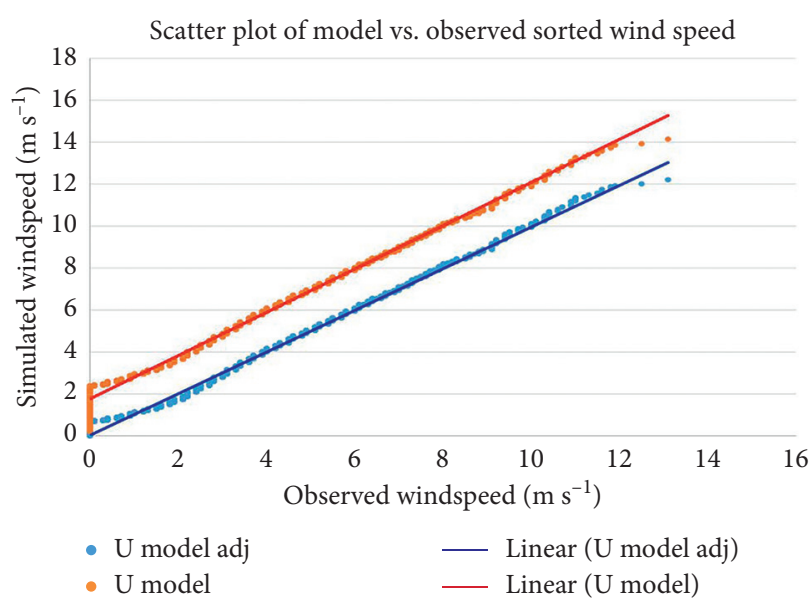

(b)

Figure 3: The values of $\alpha$ as a function of wind speed (a), and (b) scatter plot of model vs. observed wind speeds ( $\mathrm{m} \mathrm{s}^{-1}$ ) for before bias correction (red) and after bias correction (blue).

$12 \mathrm{~m} \mathrm{~s}^{-1}$ have relatively smaller bias than at other wind speed values. Thus, overall the adjusted method is feasible to apply wind speed higher than $4 \mathrm{~m} \mathrm{~s}^{-1}$.

2.4. Calculation of Wind Power Density. Wind power density of a region can be determined using the probability distribution function of wind speed $[7,35,36]$. In this study, we employed the Weibull distribution function, which has been widely applied to calculate wind energy density [36-39]. The probability density function $p(v)$ and a cumulative probability function $P(v)$ of the Weibull distribution are defined as follows [36]:

$$
\begin{aligned}
& p(v)=\left(\frac{k}{c}\right)\left(\frac{v}{c}\right)^{k-1} \exp \left[-\left(\frac{v}{c}\right)^{k}\right], \\
& P(v)=1-\exp \left[-\left(\frac{v}{c}\right)^{k}\right],
\end{aligned}
$$

where $c$ and $k$ are the Weibull shape and scale parameters, respectively, and $v$ is the wind speed. The shape parameter $c$ describes the skewness of the distribution function, while the scale parameter $k$ has wind speed units and is proportional to the average wind speed calculated from the entire distribution. Weibull shape and scale parameters $c$ and $k$ can be calculated as follows:

Logarithmic transformation of the distribution function $P(v)$ was used to obtain the following:

$$
k \ln (v)-k \ln (c)=\ln [-\ln (1-P(v))] .
$$

Let $x=\ln (v)$ and $y=\ln [-\ln (1-P(v))]$ to obtain the following form:

$$
y=A x+B,
$$

where $A=k$ and $B=-\mathrm{k} \ln (c), c=\exp (-\mathrm{B} / \mathrm{A})$.

The percentage probability for each wind class $i$ can be defined as follows:

$$
p\left(v_{i}\right)=\frac{f_{i}}{\sum_{i=1}^{N} f_{i}}=\frac{f_{i}}{n} \quad(i=1,2, \ldots, N) .
$$

The cumulative probability of wind class $i$ will be calculated using the following formula:

$$
P\left(v_{i}\right)=\sum_{j=1}^{i} p\left(v_{j}\right) .
$$

The coefficients $A$ and $B$ can be calculated using the leastsquares method as follows:

$$
A=\sum_{i=1}^{N}\left(x_{i}-\bar{x}\right)\left(\frac{\left.y_{i}-\bar{y}\right)}{\sum_{i=1}^{N}\left(x_{i}-\bar{x}\right)^{2}, B=\bar{y}-A \bar{x}}\right.
$$

wher: $x_{\mathrm{i}}=\ln \left(v_{i}\right), y_{i}=\ln \left[-\ln \left(1-P\left(v_{i}\right)\right)\right]$,

$$
\bar{x}=\frac{1}{N} \sum_{i=1}^{N} p\left(v_{i}\right) x_{i}, \bar{y}=\frac{1}{N} \sum_{i=1}^{N} p\left(v_{i}\right) y_{i} .
$$

Wind power density $P / A$ will be calculated from coefficients $c$ and $k$ of Weibull function as follows:

$$
\frac{P}{A}=\int_{o}^{\infty} \frac{1}{2} \rho v^{3} f(v) \mathrm{d} v=\frac{1}{2} \rho c^{3} \Gamma\left(\frac{k+3}{k}\right),
$$

where $\Gamma$ is gamma function and $\rho$ is air density.

\section{Results}

3.1. Model Verification and Wind Speed Adjustment. Simulated wind speeds are verified against FNL analysis and observation at Bac Lieu station. Figure 4 shows the monthly mean of wind speeds at Bac Lieu station for original and adjusted WRF simulation, station observation at $20 \mathrm{~m}$ level, and FNL analysis at $10 \mathrm{~m}$ level. The model data are from the $2 \mathrm{~km}$ resolution domain. It can be seen that both original WRF and FNL data overestimate wind speeds at Bac Lieu (Figure 4). The mean bias of the WRF simulation is about 


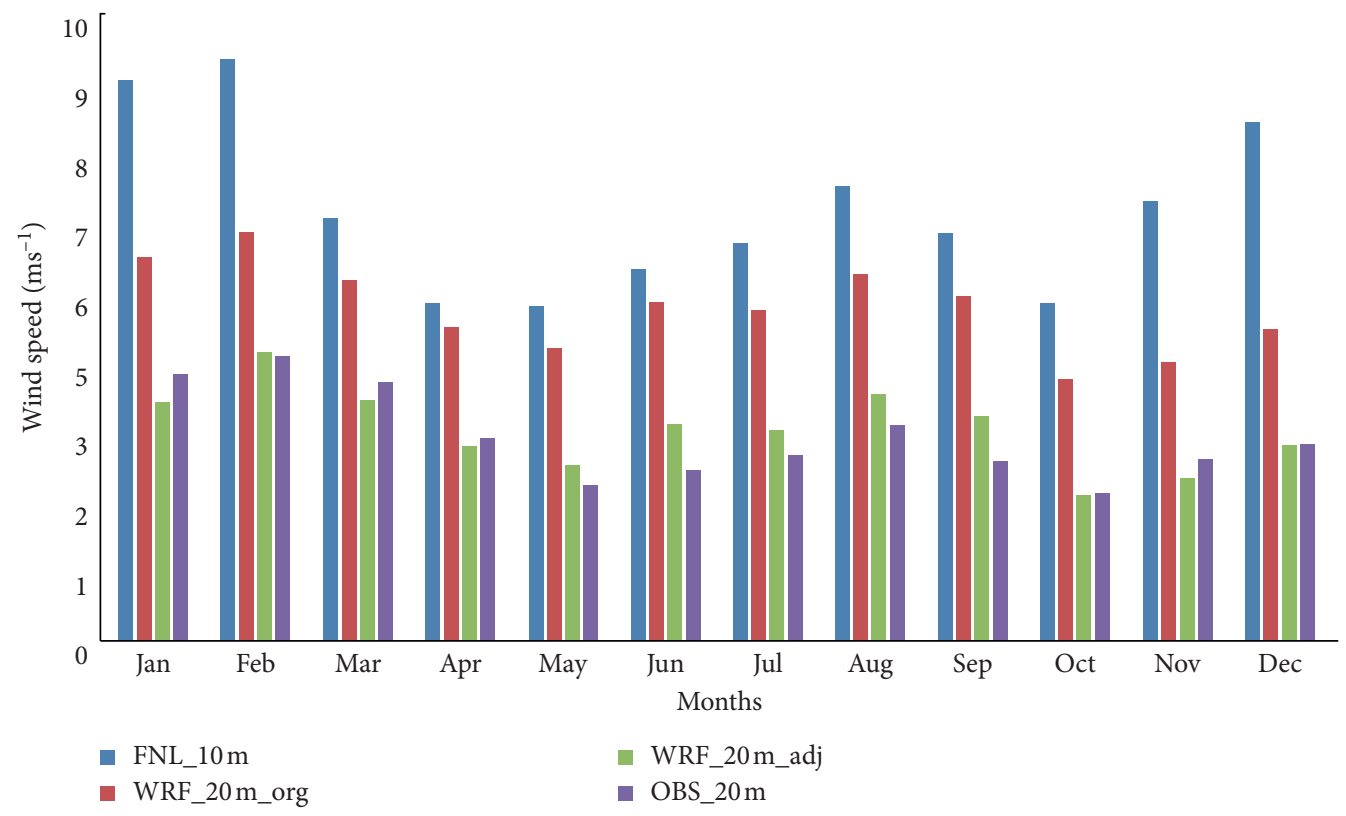

Figure 4: Monthly mean of wind speeds $\left(\mathrm{m} \mathrm{s}^{-1}\right.$ ) at $10 \mathrm{~m}$ level from FNL (blue), at $20 \mathrm{~m}$ level from observation (purple) and WRF model at $2 \mathrm{~km}$ resolution for unadjusted (red) and adjusted (green) at Bac Lieu station.

$2 \mathrm{~m} \mathrm{~s}^{-1}$. Although FNL data are at the $10 \mathrm{~m}$ level, the FNL wind speeds are significantly stronger than simulated and observed wind speeds at the $20 \mathrm{~m}$ level. Note that FNL data are not available at the $20 \mathrm{~m}$ level. Because wind speed in the low boundary layer increases with height, the wind speed at the $20 \mathrm{~m}$ level should be stronger than that at the $10 \mathrm{~m}$ level. It can imply that FNL wind speeds at the $20 \mathrm{~m}$ level (if available) should be more overestimated. In the winter months (December, January, February), FNL wind speed (Figure 4, blue) is almost double the observed values (Figure 4, purple). The too strong wind speed in FNL suggested that the FNL product should not be directly used for wind resource assessment; a downscale model simulation is required.

With high $(2 \mathrm{~km})$ resolution, in spite of overestimating wind speed, WRF produces much better wind speed in comparison to FNL data, especially in wintertime. The overestimation problem can be overcome by wind speed adjustment following the method mention in Section 2. The adjustment process is applied for every single wind speed value before wind statistics are calculated. After adjustment, WRF-simulated winds at $2 \mathrm{~km}$ resolution (Figure 4, green) are reasonably well agreed with observation (Figure 4, purple). The difference in mean wind speed at $20 \mathrm{~m}$ height between adjusted simulated wind speed and observation is $0.1 \mathrm{~m} \mathrm{~s}^{-1}$. The correlation is 0.82 . Thus, the adjusted wind speeds may be good for estimating wind energy at location without observation, investigating features of the spatial and temporal distribution of local winds, and constructing wind density maps for the research region.

Histograms of wind speed distribution and Weibull function at Bac Lieu for observation and adjusted simulation at $20 \mathrm{~m}$ height are shown in Figure 5. The wind speeds are classified into 14 groups with $1 \mathrm{~m} \mathrm{~s}^{-1}$ interval. It can be seen that both the histogram of wind speed and fitting Weibull function of the simulated winds agreed well with observation. Wind speed values are mostly in the range of 1.5 to $5.5 \mathrm{~m} \mathrm{~s}^{-1}$ for both observation and simulation. The most significant differences occur at bin of $1.5 \mathrm{~m} \mathrm{~s}^{-1}$, where the model overestimates wind speeds, and $3.5 \mathrm{~m} \mathrm{~s}^{-1}$, where the model underestimates wind speeds (Figure 5). The Weibull shape parameter $(k)$ from the model simulation is 1.68 , which is almost equal to the value of observation $(k=1.72)$. The Weibull scale parameters computed from simulated and observed wind are 3.73 and 3.79 , respectively (Table 2 ). The wind power densities at the $20 \mathrm{~m}$ level calculated from the coefficients $c$ and $k$ of the Weibull function for monitoring and simulation are $53.4 \mathrm{~W} \mathrm{~m}^{-2}$ and $52.6 \mathrm{~W} \mathrm{~m}^{-2}$, respectively (Table 2). Table 3 shows that the simulated wind data frequency and probability densities calculated from the Weibull function at Bac Lieu station reasonably agree well with those of observation.

As shown in Section 2 and Figure 3, the adjustment method is applied to adjust wind speed for every single wind speed value at any grid point at any level in the lowest $200 \mathrm{~m}$ of the boundary layer. The degree of adjustment is only dependent on the magnitude of simulated wind speed (Figure 3). To construct wind speed map at different levels, the adjustment is applied for wind at other levels in the lower (surface to $200 \mathrm{~m}$ ) boundary layer. Figure 6 shows vertical profiles of adjusted wind speeds computed from WRF simulation at Bac Lieu station. The red dots mark simulated wind speed at the levels. The black curve is the best fitting logarithm function of the wind speed profile. It can be seen that the simulated wind speeds at Bac Lieu station at all levels from the surface to $200 \mathrm{~m}$ almost exactly follow the best fitting logarithm function (Figure 6). The same process is applied for wind speeds at all grid points in the $2 \mathrm{~km}$ domain to construct wind speed and wind energy maps at different levels from surface to $200 \mathrm{~m}$. 


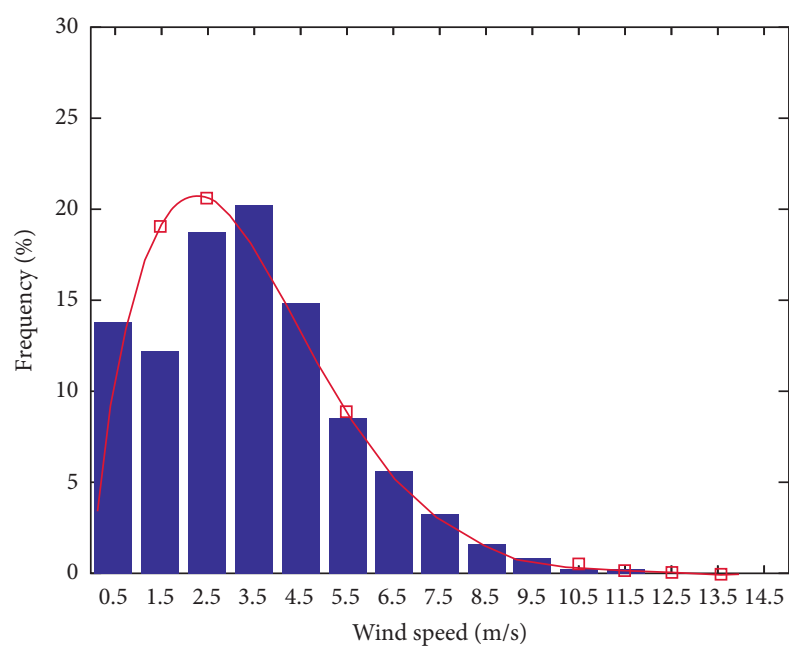

(a)

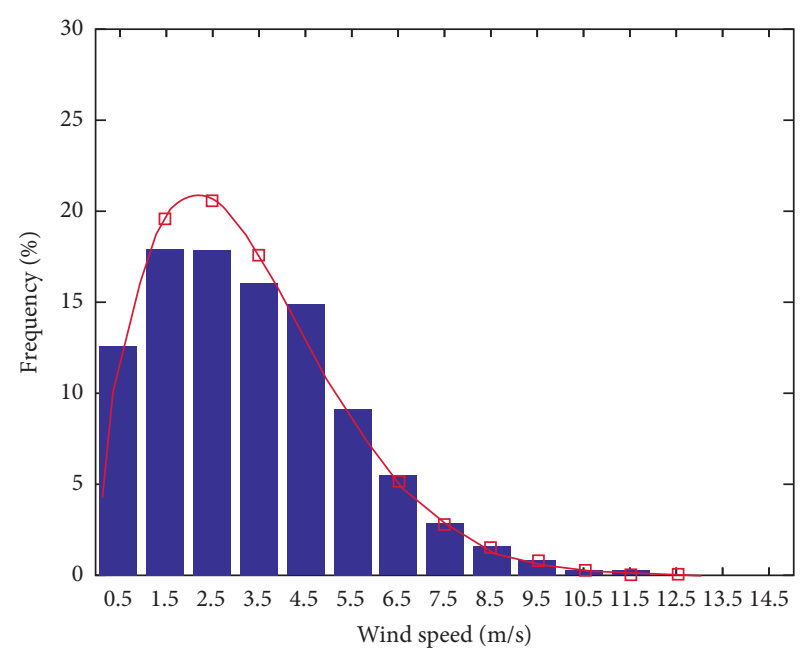

(b)

FIGURE 5: Histogram of wind speed distribution (bar) and Weibull function (line) at Bac Lieu station for (a) observation and (b) simulation.

TABle 2: The Weibull parameters and wind power density for observation and simulation at Bac Lieu station.

\begin{tabular}{lcc}
\hline Parameter & Observation & Simulation \\
\hline Average wind speed & 3.3 & 3.4 \\
Weibull shape parameter (k) & 1.72 & 1.68 \\
Weibull scale parameter (c) & 3.79 & 3.73 \\
Wind power density & 53.4 & 52.6 \\
\hline
\end{tabular}

TABLE 3: Observed and simulated wind data frequency and probability density calculated from the Weibull function at Bac Lieu station.

\begin{tabular}{lccccccccc}
\hline$i$ & $V$ & $f(\mathrm{obs})$ & $F(\mathrm{mod})$ & $p(\mathrm{obs})$ & $p(\mathrm{mod})$ & $p(\mathrm{obs})$ & $p(\bmod )$ & $P w(\mathrm{obs})$ & $P w(\mathrm{mod})$ \\
\hline 1 & 0.5 & 1795 & 1638 & 13.75 & 12.55 & 0.1375 & 0.1255 & 10.28 \\
2 & 1.5 & 1593 & 2351 & 12.21 & 18.01 & 0.2596 & 0.3056 & 19.02 \\
3 & 2.5 & 2447 & 2337 & 18.75 & 17.91 & 0.4471 & 0.4847 & 20.62 \\
4 & 3.5 & 2639 & 2108 & 20.22 & 16.15 & 0.6492 & 0.6462 & 17.89 \\
5 & 4.5 & 1939 & 1914 & 14.86 & 14.66 & 0.7978 & 0.7928 & 13.38 \\
6 & 5.5 & 1092 & 1204 & 8.37 & 9.22 & 0.8815 & 0.8851 & 8.89 \\
7 & 6.5 & 735 & 712 & 5.63 & 5.46 & 0.9378 & 0.9396 & 5.33 \\
8 & 7.5 & 420 & 379 & 3.22 & 2.90 & 0.9700 & 0.9687 & 2.92 \\
9 & 8.5 & 209 & 240 & 1.60 & 1.84 & 0.9860 & 0.9871 & 1.47 \\
10 & 9.5 & 118 & 106 & 0.90 & 0.81 & 0.9950 & 0.9952 & 0.69 \\
11 & 10.5 & 48 & 43 & 0.37 & 0.330 .14 & 0.9987 & 0.9985 & 0.30 \\
12 & 11.5 & 15 & 18 & 0.12 & 0.02 & 0.9998 & 0.9998 & 0.12 \\
13 & 12.5 & 1 & 2 & 0.01 & & 0.9999 & 1.0000 & 0.05 \\
14 & 13.5 & 1 & & 0.01 & & 1.0000 & & 0.30 \\
\end{tabular}

\subsection{Spatial Distribution of Annual Mean Wind Speeds and} Wind Power Density. Because of limitations in data at meteorological wind tower, maps of the spatial distribution of wind speeds at different levels in the lower boundary are important for wind resource assessment. The wind speed maps at the most common levels for wind energy assessment, including 10, 20,40,50,60,80, 100, 150, and $200 \mathrm{~m}$ levels, were constructed using adjusted wind speeds for wind resource assessment over the Southern Vietnam region. In this article, only wind speed maps at 20,50,100, and $200 \mathrm{~m}$ levels are presented (Figure 7).

Figure 7 represents the annual mean of wind speeds computed from 731 high-resolution $(2 \mathrm{~km})$ WRF model runs from January $1^{\text {st }} 2016$ to December $31^{\text {st }} 2017$. The figure shows that wind distributions are significantly affected by friction and topography. At all levels, the annual highest mean wind speed occurs in the coastal regions of Bac Lieu, Soc Trang, Tra Vinh, and Ben Tre provinces. The mean wind speeds at the provinces are about $3.5-4.5 \mathrm{~m} \mathrm{~s}^{-1}$ at $20 \mathrm{~m}$ level; $4.0-5.5 \mathrm{~m} \mathrm{~s}^{-1}$ at $50 \mathrm{~m}$ level; $5.0-6.0 \mathrm{~m} \mathrm{~s}^{-1}$ at $100 \mathrm{~m}$ level; $5.5-7.0 \mathrm{~m} \mathrm{~s}^{-1}$ at $200 \mathrm{~m}$ level (Figure 7). Mean wind speeds are rapidly increased with height due to the reduction in the effect of surface friction with height in the lower boundary layer. Wind speed rapidly decreased from coast to inland due to larger surface friction over land than over the ocean. In the northern region, the mean wind speeds are low 


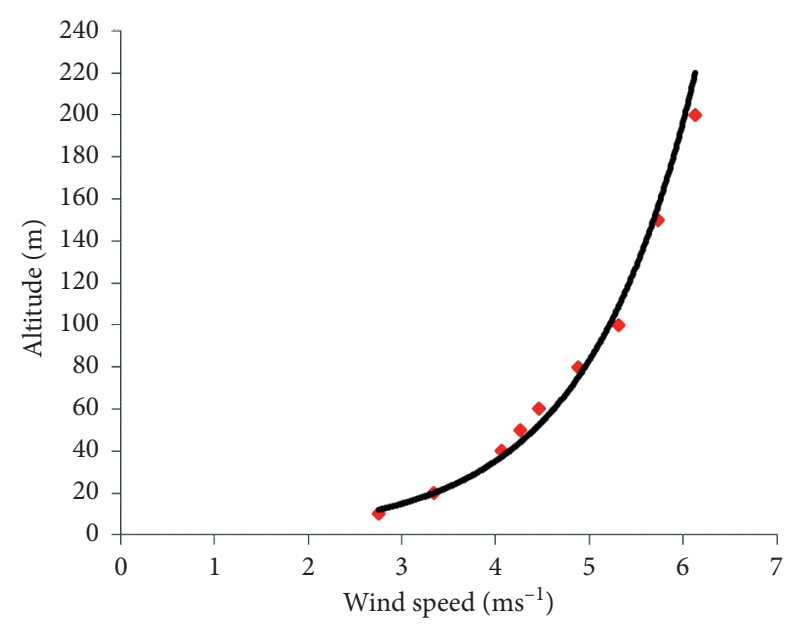

Figure 6: Vertical profiles of adjusted wind speed $\left(\mathrm{m} \mathrm{s}^{-1}\right)$ from WRF simulation at Bac Lieu station. The red dots mark simulated wind speed at the levels. The black curve is the best fitting logarithm function of the wind speed profile.

because of the far distance from the ocean. Mean wind speeds over the region are about $2.0-3.0 \mathrm{~m} \mathrm{~s}^{-1}, 3.0-4.0 \mathrm{~m} \mathrm{~s}^{-1}$, $3.5-4.5 \mathrm{~m} \mathrm{~s}^{-1}$, and $4.5-5.5 \mathrm{~m} \mathrm{~s}^{-1}$ at $20 \mathrm{~m}, 50 \mathrm{~m}, 100 \mathrm{~m}$, and $200 \mathrm{~m}$ levels, respectively (Figure 7).

To construct wind power density maps, based on the observed wind speed from 2016 to 2017, Weibull's shape and scale parameters, $c$ and $k$, are firstly calculated. The parameters are then used to construct wind power density at all levels. Adjusted model wind speeds are used for wind power density calculation. The spatial distributions of wind power density (Figure 8) are very similar to those of wind speeds (Figure 7). Values of wind power density are larger at coastal region than inland, larger at upper levels than at lower levels (Figure 8).

At $20 \mathrm{~m}$ height (Figure 8(a)), the mean wind power density at Bac Lieu, Soc Trang, Tra Vinh, and Ben Tre ranges from 60 to $120 \mathrm{~W} \mathrm{~m}^{-2}$. The wind power density at the western coastal areas of Ca Mau and Kien Giang ranges from 40 to $70 \mathrm{~W} \mathrm{~m}^{-2}$. Inland, over An Giang and Dong Thap provinces, the wind power density is only about $20-30 \mathrm{~W} \mathrm{~m}^{-2}$. The wind power density along the river higher than the surroundings has values from $40 \mathrm{~W} \mathrm{~m}^{-2}$ to $70 \mathrm{~W} \mathrm{~m}^{-2}$ in river areas (Figure $8(\mathrm{a})$ ). At $50 \mathrm{~m}$ height (Figure $8(\mathrm{~b})$ ), around Bac Lieu, the range of the annual mean wind power density is $150-170 \mathrm{~W} \mathrm{~m}^{-2}$. The values are about $100-120 \mathrm{~W} \mathrm{~m}^{-2}$ in western coastal areas. Wind power density is low with values of about $30-50 \mathrm{~W} \mathrm{~m}^{-2}$ at An Giang, Dong Thap, and Can Tho provinces (Figure 8(b)). At $100 \mathrm{~m}$ height, in eastern coastal regions, the mean wind power density ranges from 200 to $250 \mathrm{~W} \mathrm{~m}^{-2}$. Over the western coastal areas, the values of the wind power density are much less, with values of about $120-150 \mathrm{~W} \mathrm{~m}^{-2}$. Over An Giang, Dong Thap, and Can Tho provinces, the values are as low as about $80-100 \mathrm{~W} \mathrm{~m}^{-2}$ (Figure 8(c)). At $200 \mathrm{~m}$ height, the values of the wind power density at the eastern coastal region range from 260 to $320 \mathrm{~W}$ $\mathrm{m}^{-2}$. Over the western coastal region, the values of the wind power density are about $200-250 \mathrm{~W} \mathrm{~m}^{-2}$. In the northern provinces of the research areas, including An Giang, Dong Thap, Can Tho, and Tien Giang, the wind power density at
$200 \mathrm{~m}$ level ranges from 150 to $180 \mathrm{~W} \mathrm{~m}^{-2}$ (Figure $8(\mathrm{~d})$ ). As shown in Figure 3(b), at a high wind speed of more than $12 \mathrm{~m} \mathrm{~s}^{-1}$, the bias correction may overreduce wind speeds at $200 \mathrm{~m}$ above ground level, resulting in significantly reducing the estimated wind power density. Because the wind data are not available at a high $(200 \mathrm{~m})$ level, to deal with the uncertainty in wind speed bias correction, Figure $8(\mathrm{e})$ is to show the possibility of high values in wind power density of about $400-440 \mathrm{~W} \mathrm{~m}^{-2}$ (Figure 8(e)) in the nearshore region (Figure 8(e)). The possible high values in wind power density on Figure 8(e) should be considered and verified in the future when observed wind data at the $200 \mathrm{~m}$ above ground level are available.

Results from this work suggest that over Southern Vietnam, the eastern coastal regions of Bac Lieu, Soc Trang, Tra Vinh, and Ben Tre have the most potential to exploit wind energy. At levels below $100 \mathrm{~m}$, only regions with a distance of $10-20 \mathrm{~km}$ from the coast have relatively high values of potential wind energy. At higher levels of $150-200 \mathrm{~m}$ above ground, the zone of high values of potential wind energy can be extended to $40-50 \mathrm{~km}$ from the coast.

\subsection{Diurnal and Annual Variation of Wind Speed.} Figure 9 shows the annual mean of hourly wind speeds $\left(\mathrm{m} \mathrm{s}^{-1}\right)$ at $20 \mathrm{~m}$ level at Bac Lieu station for observations (blue) and adjusted simulation (green). It can be seen that the model reasonably well simulates wind speed and its diurnal cycle. Both simulation and observation present that wind speeds have a clear diurnal cycle with weak wind speeds of less than $2.5 \mathrm{~m} \mathrm{~s}^{-1}$ at night. Observed wind speed during the day is almost double the values at night. The strongest wind speed occurs from $13 \mathrm{LT}$ to $15 \mathrm{LT}$ when the air is the most unstable due to heating (Figure 9). The model simulates better wind speeds at night than during the day. Maximum simulated wind speed occurs at about 15 LT, whereas the observed one is at about 14 LT. Although the model underestimates wind speeds in the late morning and overestimates wind speeds in the late afternoon, the mean errors of about less than $0.5 \mathrm{~m} \mathrm{~s}^{-1}$ are relatively small. It is difficult to fully explain why the model errors are smaller at night than during the daytime. In an unstable boundary layer during daytime, the model may more poorly represent physical processes, such as turbulent mixing, radiative transport, or atmosphere-land interaction processes relating to the type of soil.

Figure 10 presents the mean of wind speed $\left(\mathrm{m} \mathrm{s}^{-1}\right)$ at $20 \mathrm{~m}$ level in the Southern Vietnam region in winter (DJF) and summer (JJA) for at night (05LT) and daytime (14LT) regimes. The figure shows an annual wind pattern of a monsoon region with northeast winds in winter and southwest winds in summer.

In winter, while wind at night is relatively strong over open ocean with a mean wind speed of about 4.5 to $6.5 \mathrm{~m} \mathrm{~s}^{-1}$, the wind is almost calm over land with a mean wind speed of about $2 \mathrm{~m} \mathrm{~s}^{-1}$ or less (Figure 10(a)). During the day, with more vertical mixing and more transporting highmomentum air from ocean to mainland, wind speed over land is much stronger (Figure 10(b)) than that at night 


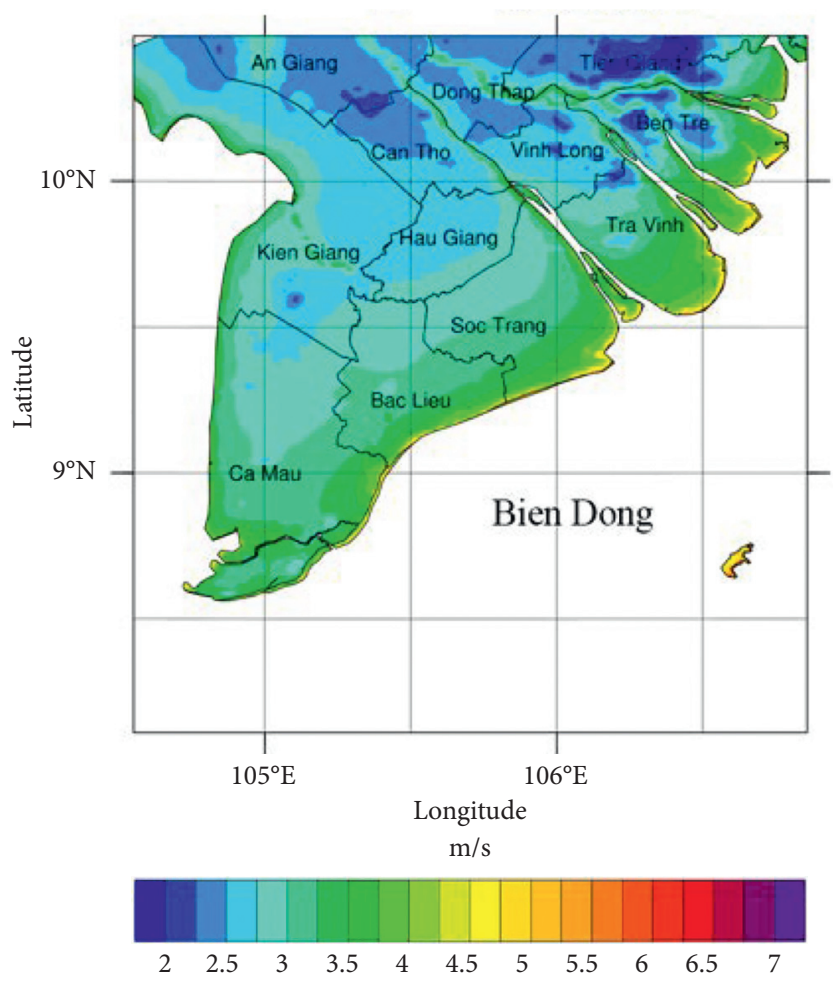

(a)

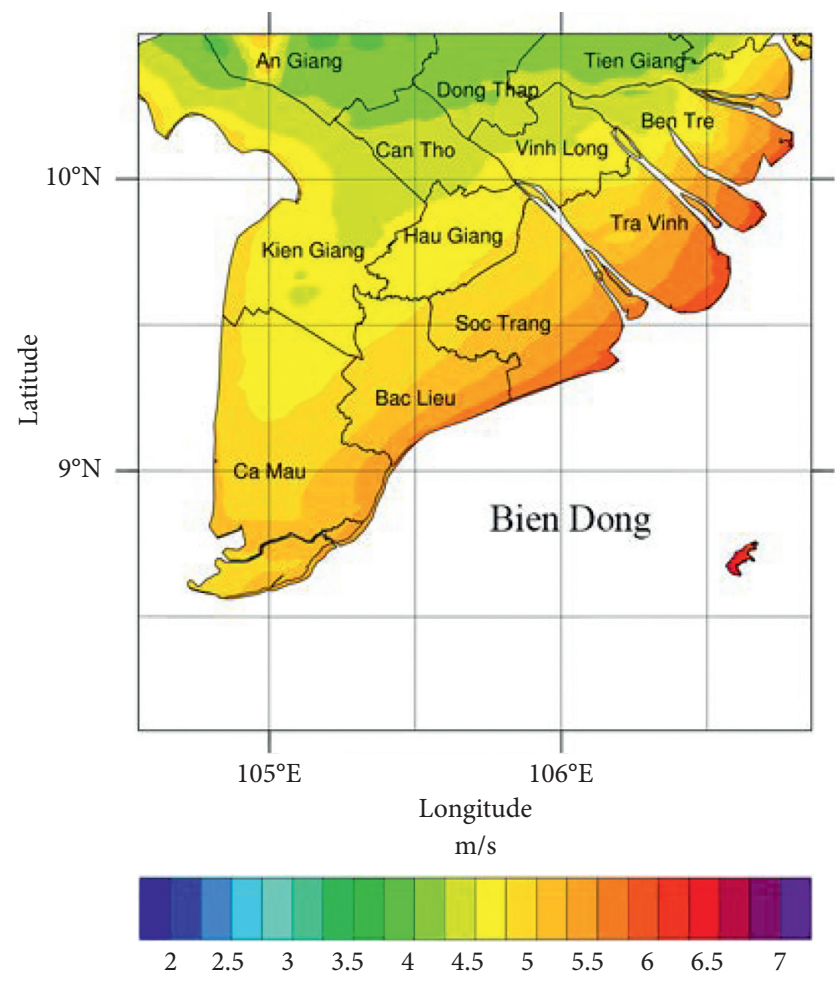

(c)

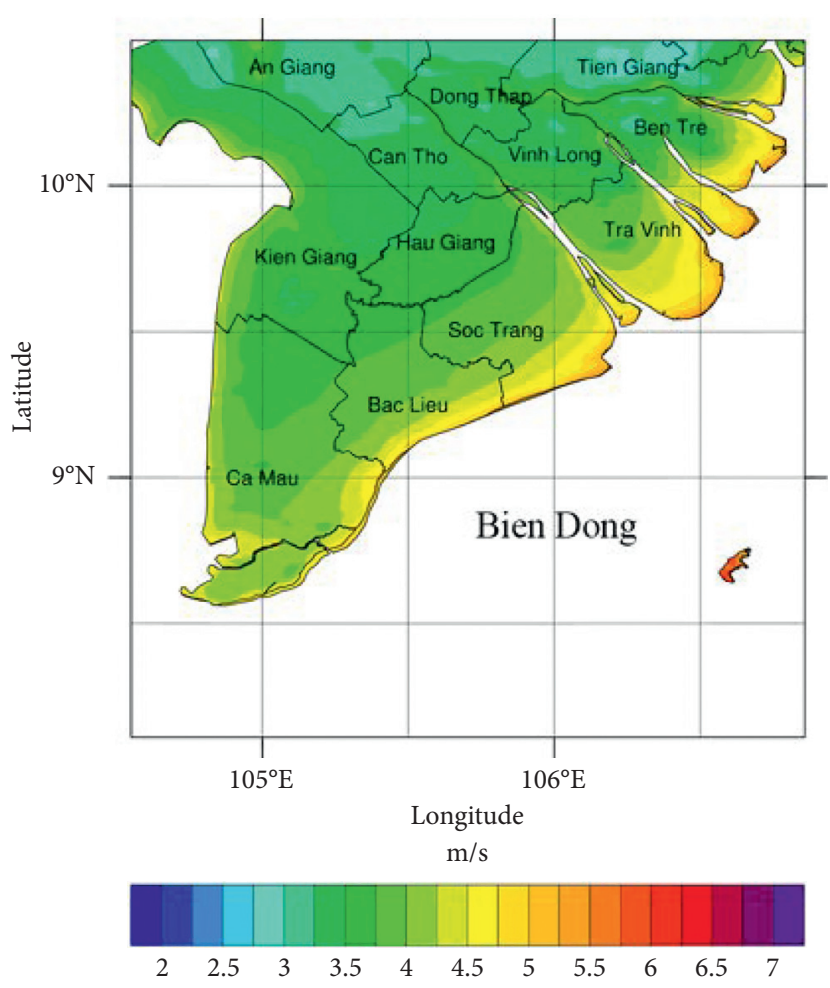

(b)

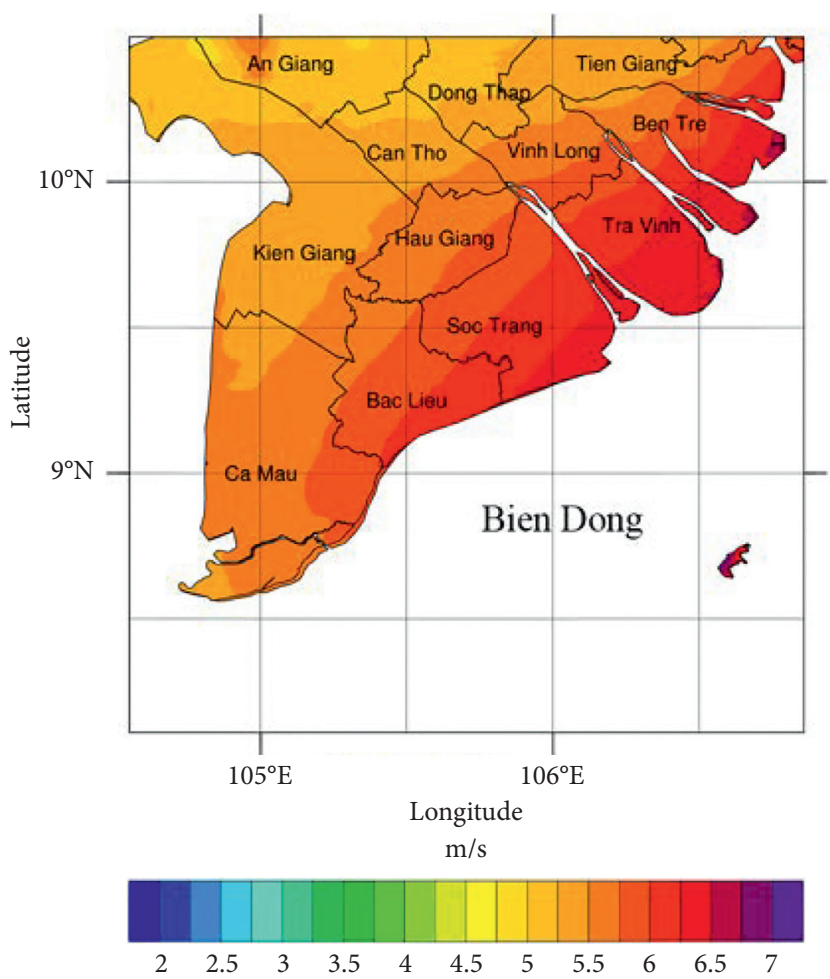

(d)

Figure 7: Annual mean of simulated wind speeds $\left(\mathrm{m} \mathrm{s}^{-1}\right.$ ) from $2 \mathrm{~km}$ resolution domain at (a) $20 \mathrm{~m}$, (b) $50 \mathrm{~m}$, (c) $100 \mathrm{~m}$, and (d) $200 \mathrm{~m}$ levels. 


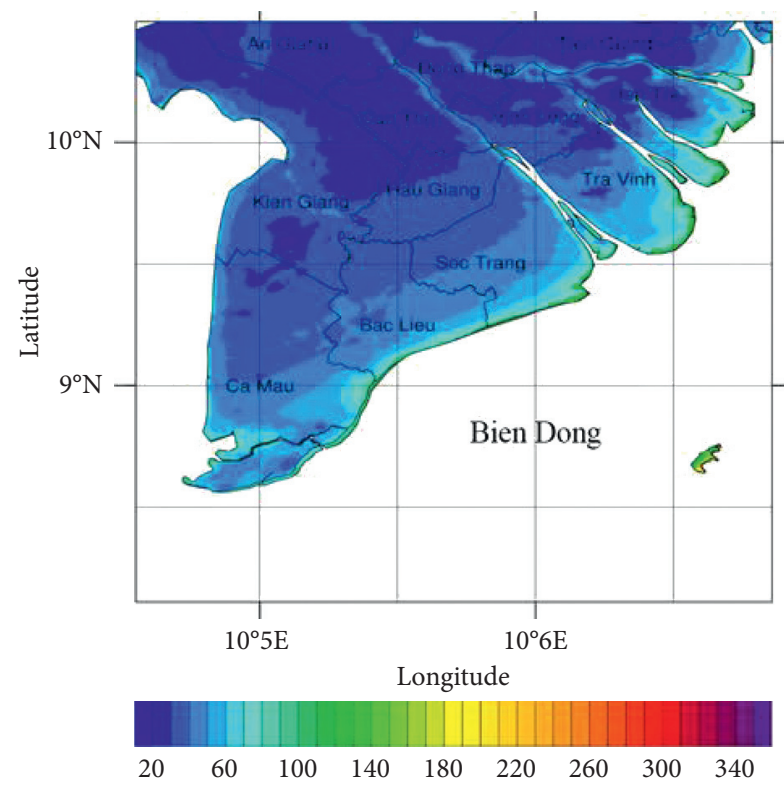

(a)

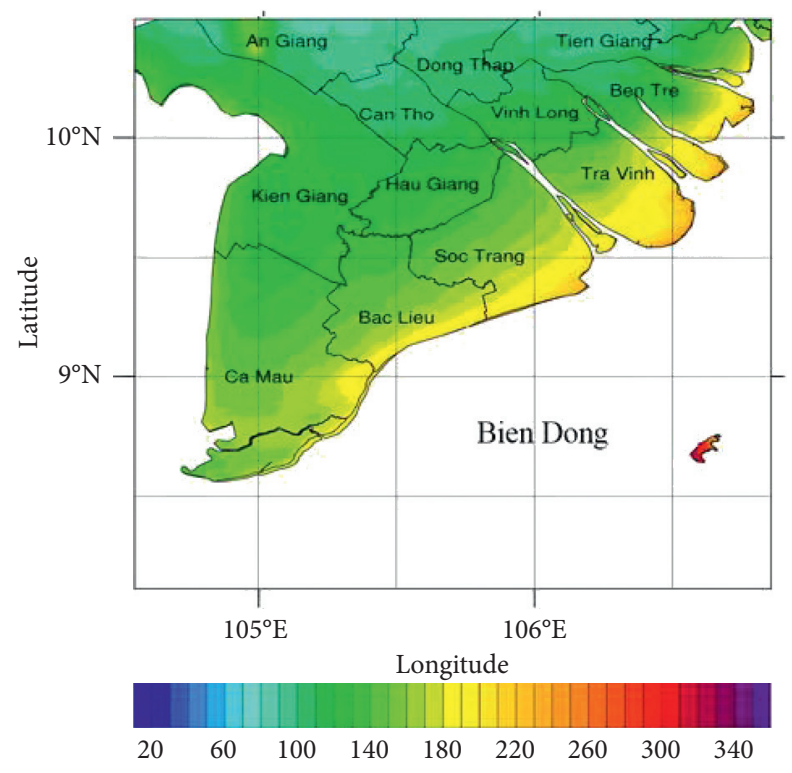

(c)

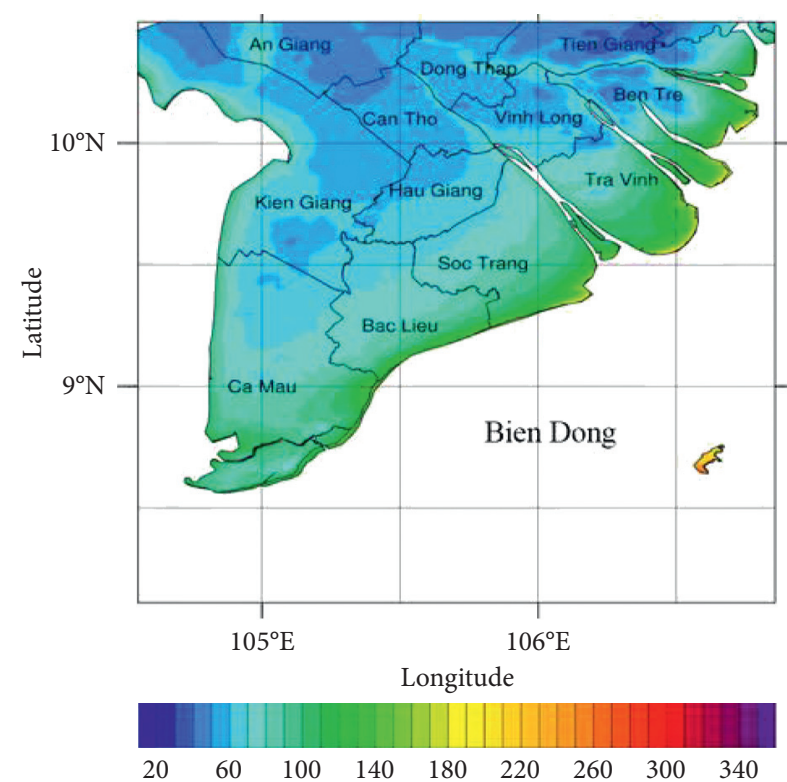

(b)

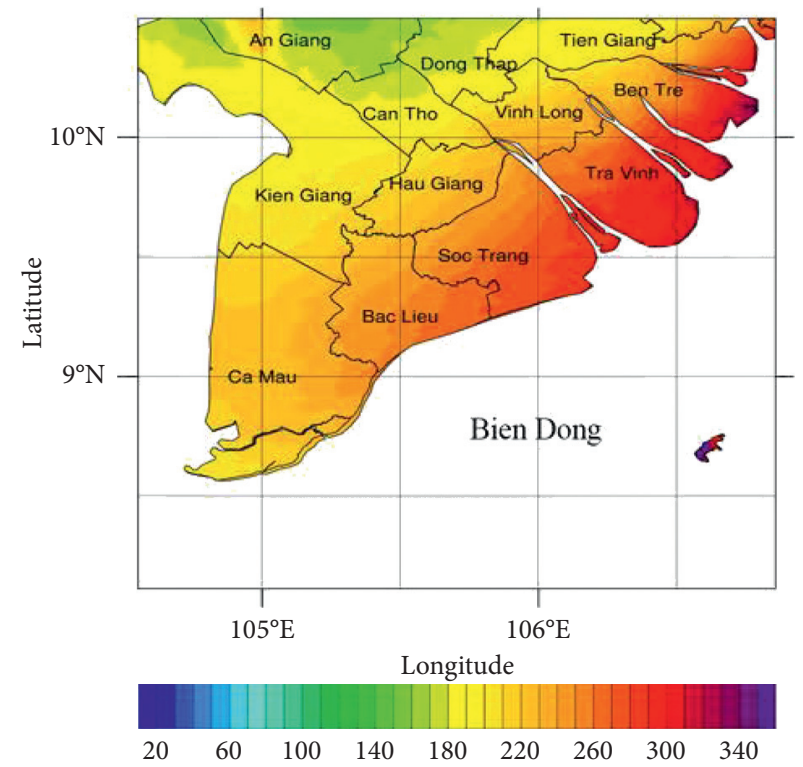

(d)

Figure 8: Continued. 


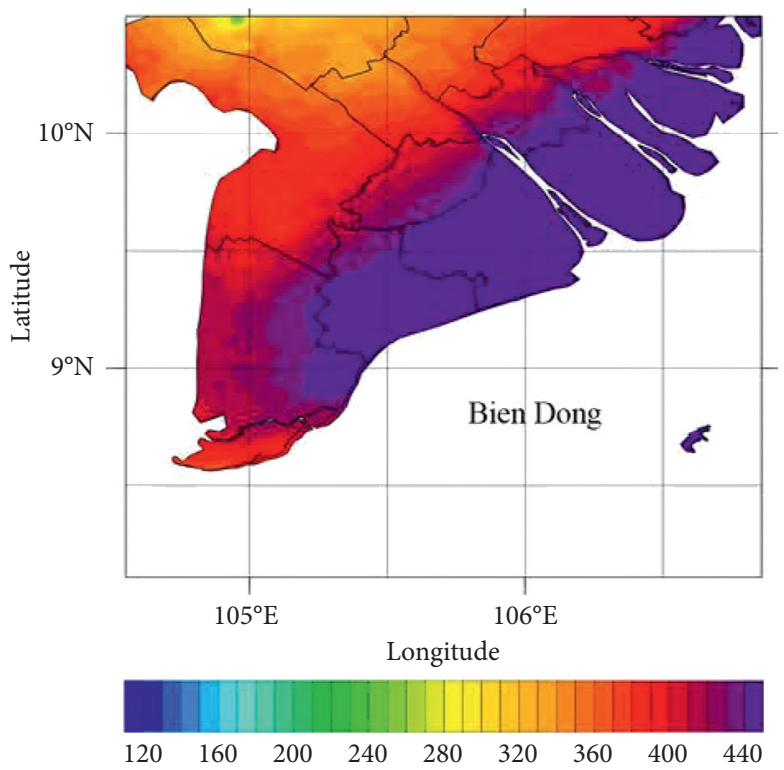

(e)

FIGURE 8: Simulated wind power density (WPD, $\mathrm{W} \mathrm{m}^{-2}$ ) computed from wind speed with bias correction at (a) $20 \mathrm{~m},(\mathrm{~b}) 50 \mathrm{~m},(\mathrm{c}) 100 \mathrm{~m}$, and (d) $200 \mathrm{~m}$ levels, and (e) $200 \mathrm{~m}$ level but without wind speed bias correction.

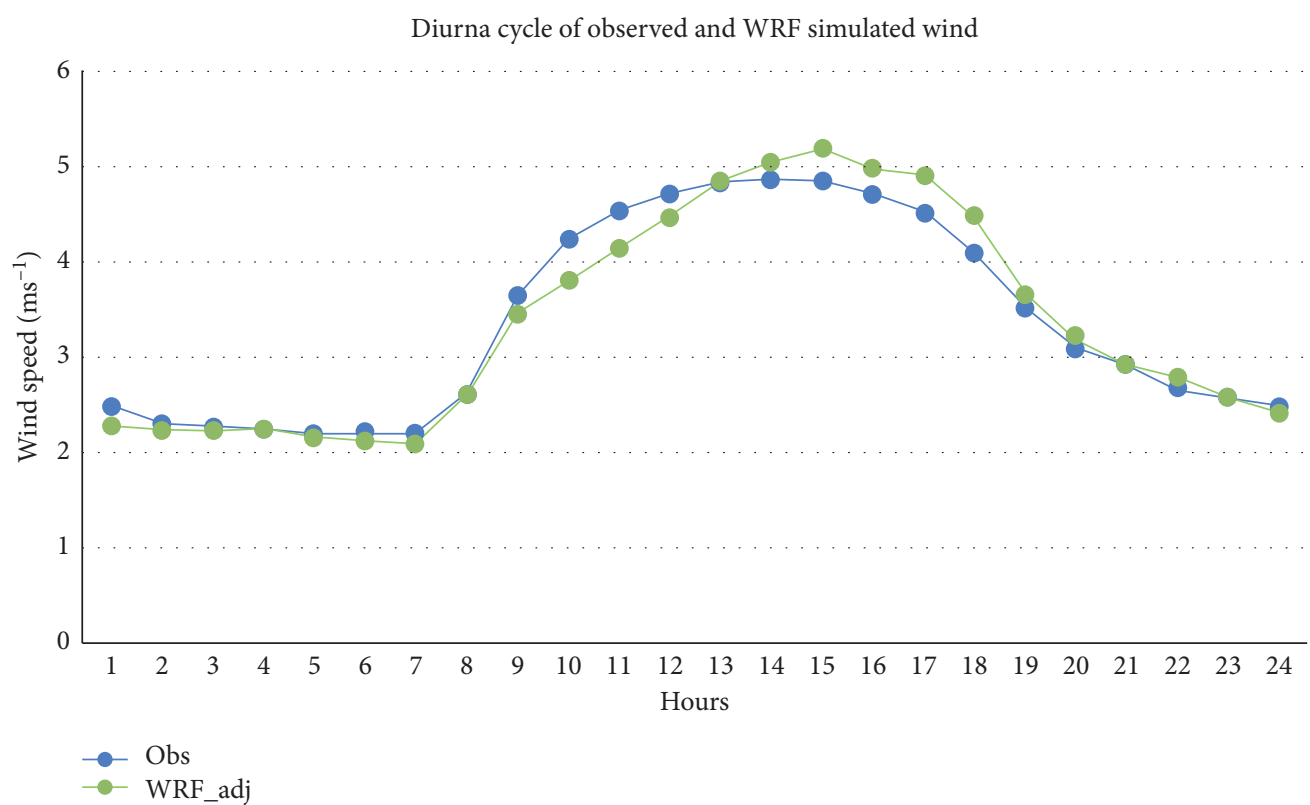

Figure 9: Diurnal cycle of wind speed $\left(\mathrm{m} \mathrm{s}^{-1}\right)$ at $20 \mathrm{~m}$ level at Bac Lieu station for observations (blue) and adjusted simulation (green). The horizontal axis is the time in the day.

(Figure 10(a)). During the day, the mean wind speed near the coastal region reaches 4.5 to $5.5 \mathrm{~m} \mathrm{~s}^{-1}$. The region with a relatively stronger wind speed of $3-4 \mathrm{~m} \mathrm{~s}^{-1}$ reaches $40-60 \mathrm{~km}$ inland from the coast (Figure 10(b)).

In summer, winds over the ocean (Figures 10(c) and 10(d)) are $1-2 \mathrm{~m} \mathrm{~s}^{-1}$ weaker than those in winter (Figures 10(a) and 10(b)). Wind speed distribution over land is totally different between night time (Figure 11(c)) and daytime (Figure 10(d)) during summer. At night, the entire Southern Vietnam region, except over river areas, has a wind speed less than $2 \mathrm{~m} \mathrm{~s}^{-1}$ (Figure 10(c)). During the day, stronger vertical mixing and transporting of highmomentum air from the ocean to mainland by southwest monsoon enhanced by land breeze effect make wind much stronger than that at night over the entire region. Mean wind speeds during daytime are mostly from 3 to $4 \mathrm{~m} \mathrm{~s}^{-1}$ (Figures 10(d)).

Figure 11 illustrates the monthly mean of observed and simulated wind speeds at Bac Lieu station in 2016. The annual cycle of wind speed shows two maxima: one in 


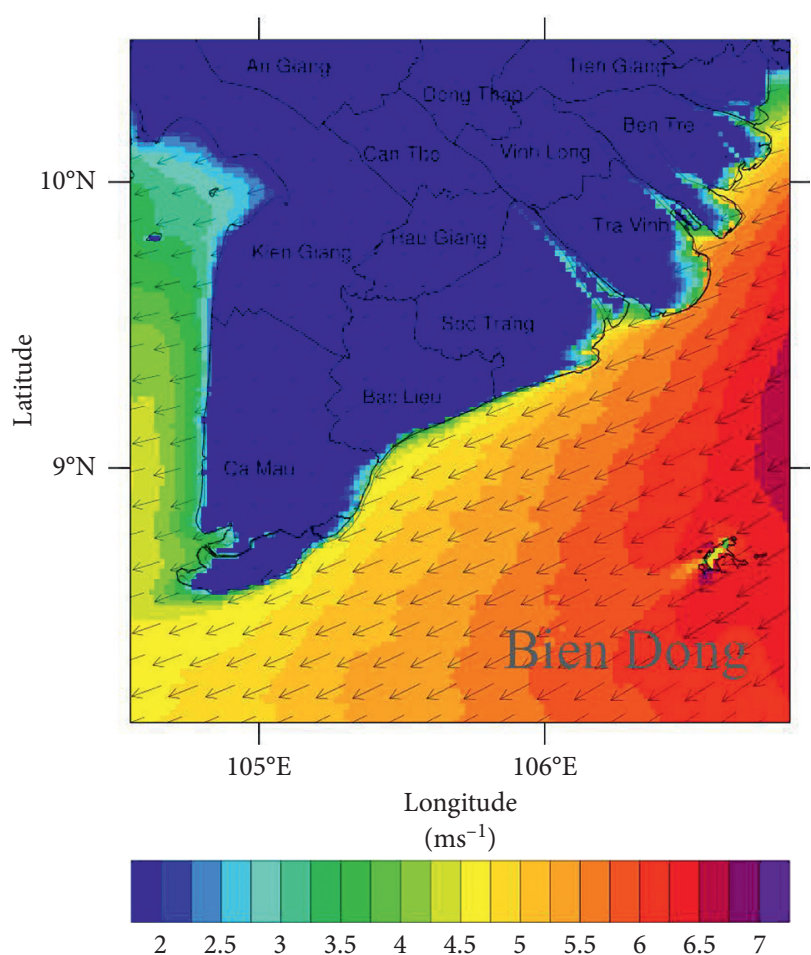

(a)

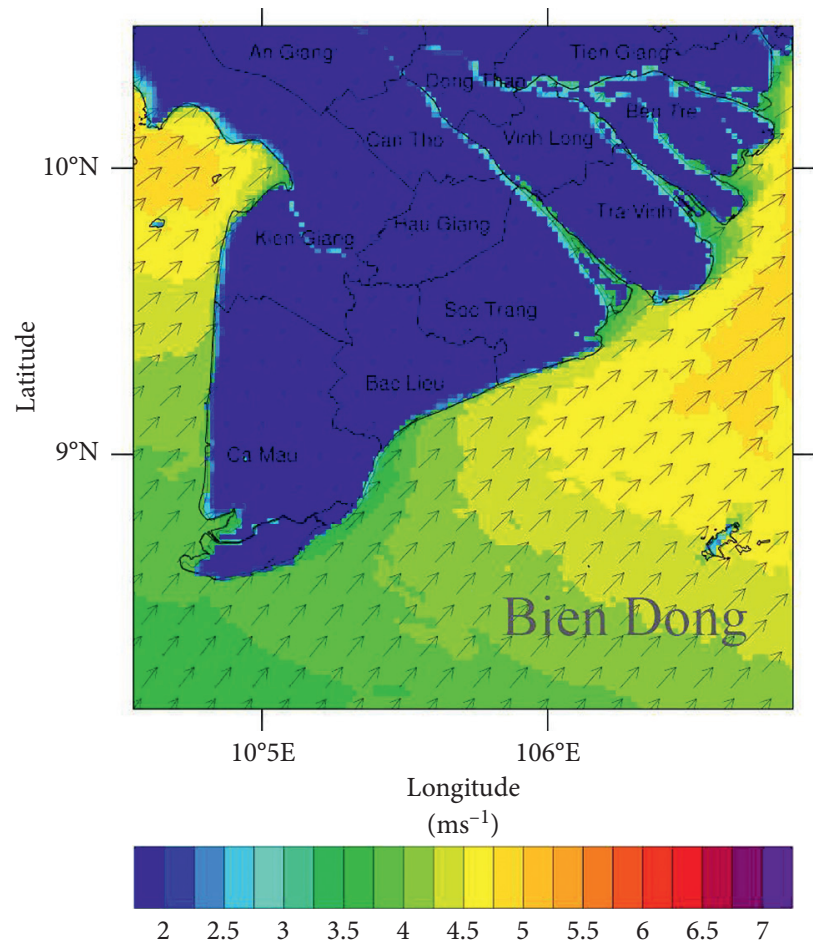

(c)

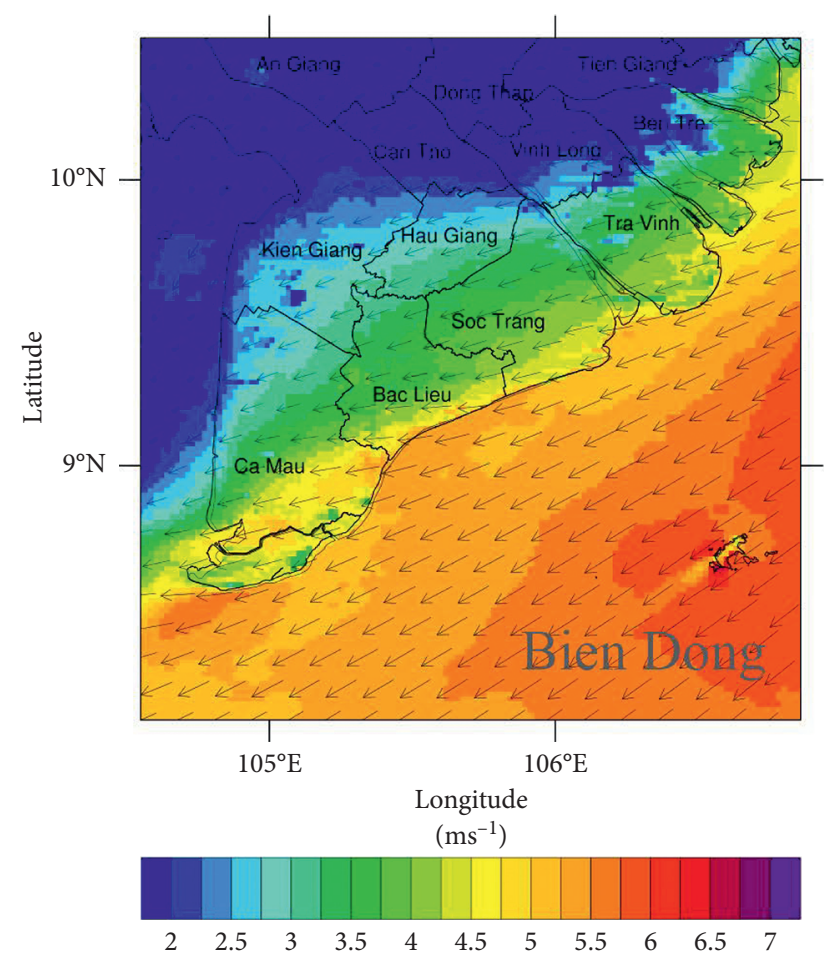

(b)

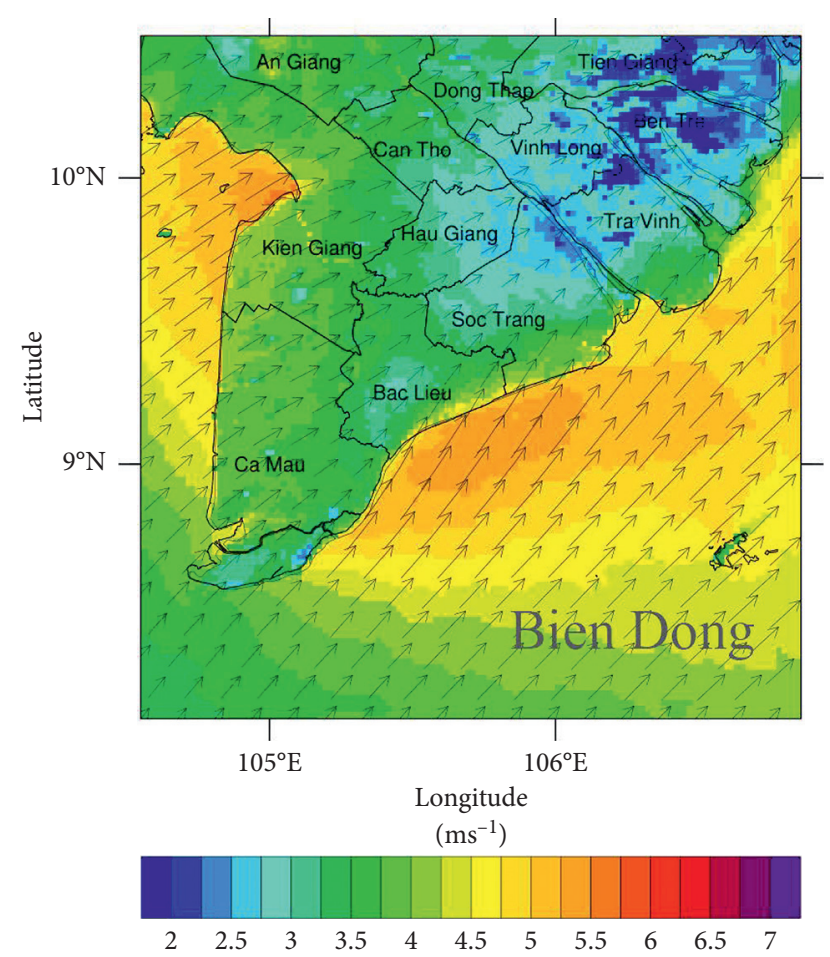

(d)

FIGURE 10: Annual mean of wind speed $\left(\mathrm{m} \mathrm{s}^{-1}\right.$ ) and wind vector (vector) at $20 \mathrm{~m}$ level in Southern Vietnam region for winter (DJF) at (a) 05 LT and (b) $14 \mathrm{LT}$ and summer (JJA) at (c) 05LT and (d) $14 \mathrm{LT}$.

February with a monthly mean wind of about $4.6 \mathrm{~m} \mathrm{~s}^{-1}$; the other in August with a monthly mean wind of about $3.6 \mathrm{~m} \mathrm{~s}^{-1}$. There are two minima that occurred in May and
October with a monthly mean wind of about $2.5 \mathrm{~m} \mathrm{~s}^{-1}$ (Figure 11). The annual variation of wind speeds with two maxima agrees with previous studies (Tran, 2007 [27]). It can 


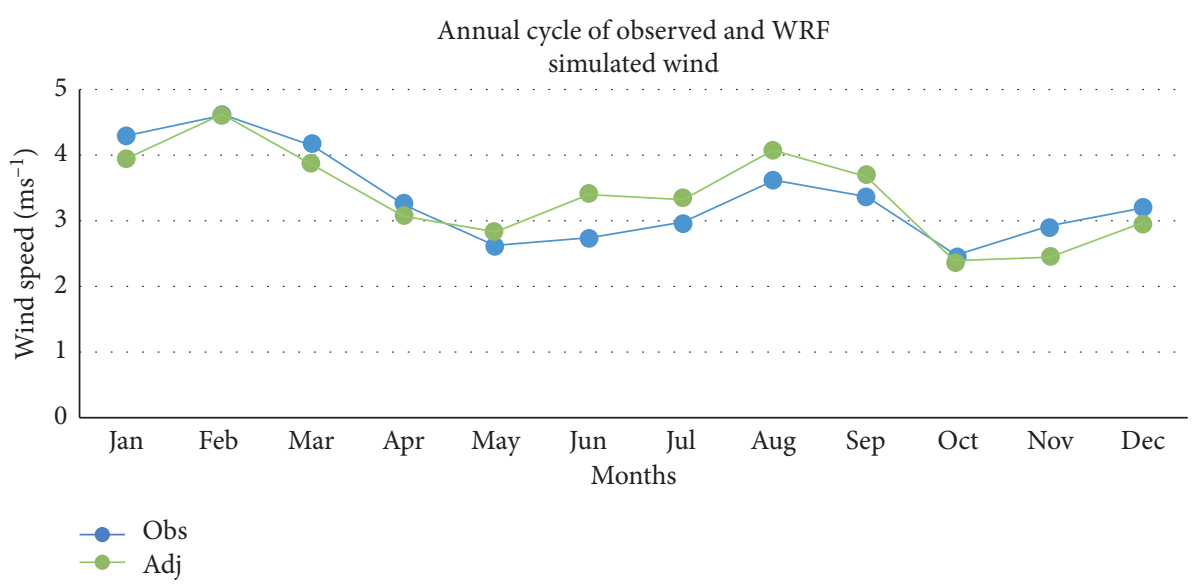

Figure 11: Monthly mean of wind speed at $20 \mathrm{~m}$ level at Bac Lieu station for observations (blue) and simulated (green).

be seen in Figure 11 that the model well captures the annual cycle of observed wind speed, including the two maxima and monthly values.

The model simulates better wind speeds in winter than in the summertime (Figure 11). In Southern Vietnam (SV), other than dividing one year into four seasons (winter, summer, fall, and spring) based mainly on temperature, there is another definition of seasons in SV based on rainfall in which one year is divided into two seasons including dry season (November to April) with much less or no rainfall and wet season (May to October) with much more rainfall. Rainfall in SV in the wet season mostly comes from convective rains in afternoon thunderstorms and mesoscale disturbances. More disturbances that are not well simulated in current model physics may be one of the reasons for lower quality in wind speed simulation in summertime than in wintertime (Figure 11).

As shown in Section 3.1, the high-resolution WRF model is much better than the FNL analysis data in regenerating wind speed at Bac Lieu station. To further see the advantages of highresolution simulation over the SV region, simulated wind speeds from the WRF model are compared with those of FNL analysis on grids. Figure 12 presents mean wind speeds from FNL analysis (Figures 12(a) and 12(b)) at one-degree resolution and WRF model at $18 \mathrm{~km}$ resolution (Figures $12(\mathrm{c})$ and $12(\mathrm{~d})$ ) in February (top) and August (bottom). The two months were selected because February (August) has the strongest wind speed in observation in winter (summer) time.

Figure 12 shows that both FNL and WRF wind speeds over the ocean in winter are stronger than those in the summertime. Over the ocean, WRF-simulated wind speeds display similar spatial distribution as the analysis but with more details because of higher resolution. In February, the northeast wind is almost perpendicular to the mountain and coastal lines of central Vietnam. Due to the orographic blocking effect, there is an anomalous high-pressure system near the coastal region of central Vietnam, resulting in a relatively weaker wind over the region and nearshore ocean (Figure 12(c)). The wind speeds decrease from upstream values of about $8 \mathrm{~m} \mathrm{~s}^{-1}$ (before reaching $16^{\circ} \mathrm{N}, 109.5^{\circ} \mathrm{E}$ ) to about $6 \mathrm{~m} \mathrm{~s}^{-1}$, when the oceanic air parcel reaches about $40 \mathrm{~km}$ from the coast (Figure 12(c)). Wind speeds significantly decrease to about $2-3 \mathrm{~m} \mathrm{~s}^{-1}$ at about $\left(15^{\circ} \mathrm{N}, 109^{\circ} \mathrm{E}\right.$ ) (Figure $12(\mathrm{c})$ ), when it reaches the coastal boundary due to the combined effect of friction and orographic blocking.

In the wintertime, there is a strong wind area over the ocean near the coastal region centered at about $\left(10.5^{\circ} \mathrm{N}\right.$, $108.5^{\circ} \mathrm{E}$ ) and extended to the south (Figures 12(a) and 12(c)). The strong wind region may be due to the funnel effect in a small friction region over the ocean. In fact, there is a highpressure anomaly with the value of $1.5 \mathrm{hPa}$ to $4 \mathrm{hPa}$ located over Vietnam mainland and coastal regions, along $10.5^{\circ} \mathrm{N}$ to $20.5^{\circ} \mathrm{N}$ (Figure $12(\mathrm{c})$ ). The wind speed anomaly at the exit region of the funnel effect associated with the high-pressure anomaly is in the same direction as the large-scale northeast monsoon winds. In addition, the exit region is over ocean with small friction. As a result, a strong wind speed region centered at about $\left(10.5^{\circ} \mathrm{N}, 108.5^{\circ} \mathrm{E}\right)$ persistently presented in analysis (Figure 12(a)) and simulated (Figure 12(c)) wind fields during wintertime. The strong wind region is one of the main reasons to make the observed wind speed over Bac Lieu region reach its annual maximum in February (Figure 11).

In the summertime, with dominated southwest monsoon, the strong wind region due to the funnel effect moved to the location of about $\left(11.5^{\circ} \mathrm{N}, 109.5^{\circ} \mathrm{E}\right)$ and extended to the north (Figures 12(b) and 12(d)) as the exit location of the funnel effect changes with southwest monsoon direction. The magnitude of strongest wind speed at the wind maximum center $\left(11.5^{\circ} \mathrm{N}, 109.5^{\circ} \mathrm{E}\right)$ in August is only about $9 \mathrm{~m} \mathrm{~s}^{-1}$ (Figure $12(\mathrm{~d})$ ), which is much weaker than that in wintertime with maximum wind speed at $\left(10.5^{\circ} \mathrm{N}, 108.5^{\circ} \mathrm{E}\right)$ of over $11 \mathrm{~m} \mathrm{~s}^{-1}$ (Figure 12(c)). Because the location of maximum wind center $\left(11^{\circ} \mathrm{N}, 110^{\circ} \mathrm{E}\right)$ due to funnel effect in the summertime is relatively far from the Bac Lieu region and the extended region is to the north, the maximum wind speed in August over Bac Lieu region (Figure 11) is not due to funnel effect but the strengthening of the dominated large-scale southwest monsoon in August (Figures. 12(b) and $12(\mathrm{~d}))$. 


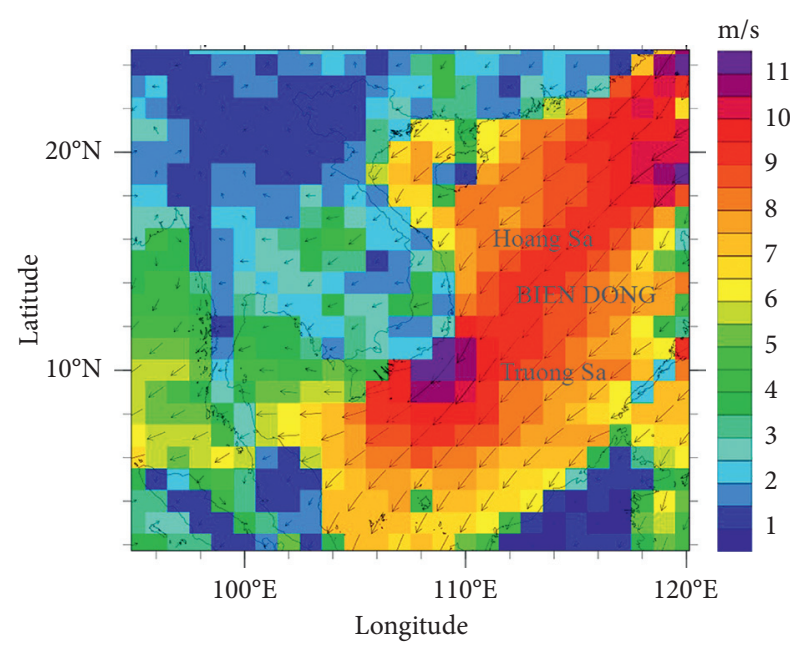

(a)

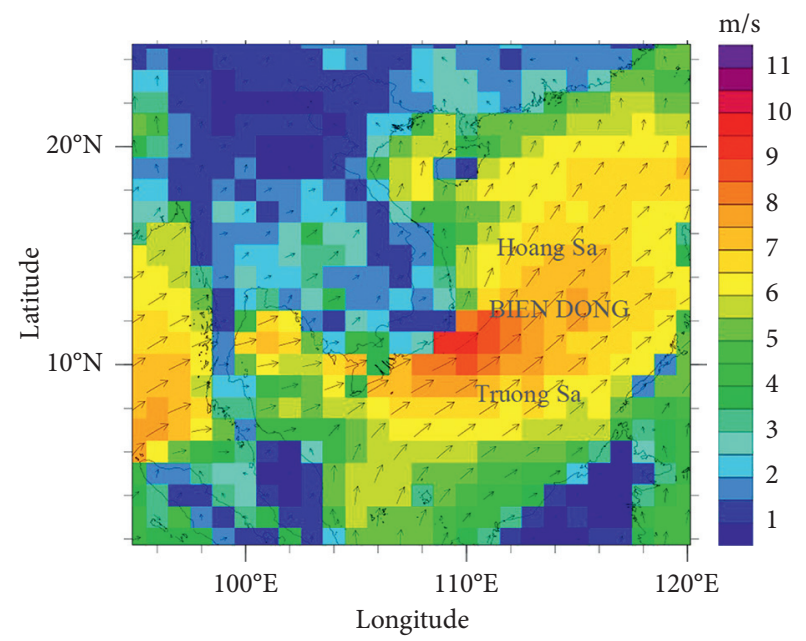

(c)

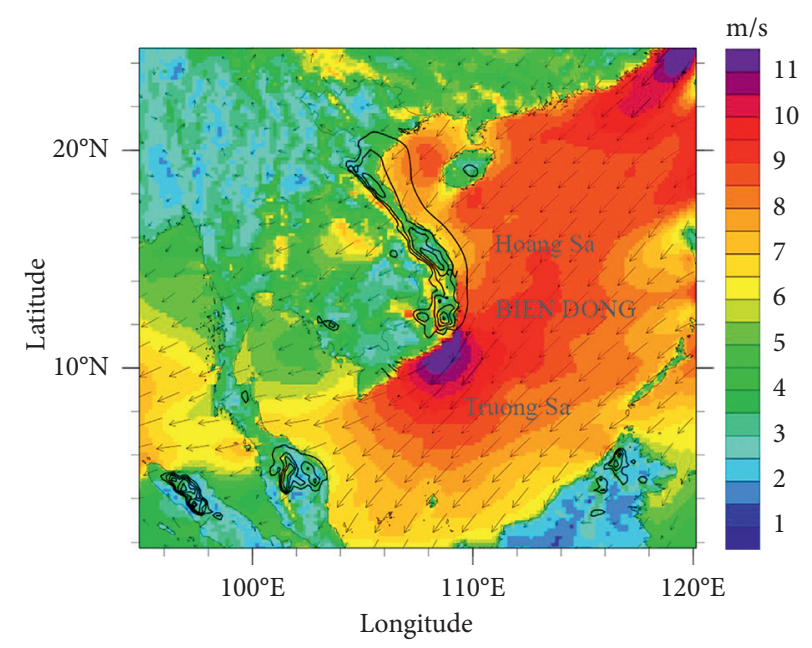

(b)

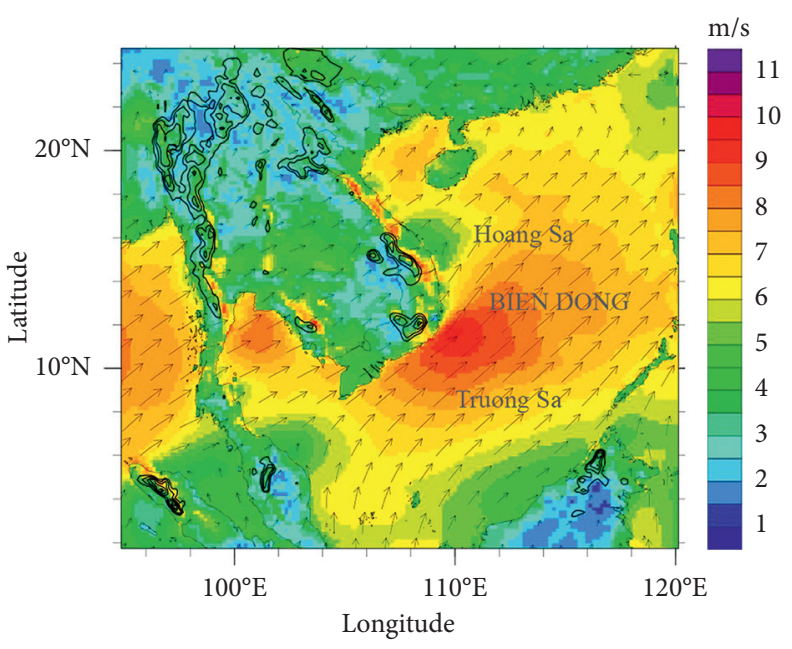

(d)

FIgUre 12: Mean wind speed at $10 \mathrm{~m}$ height from FNL analysis data for Feb (a) and Aug (b) and WRF model at $18 \mathrm{~km}$ resolution for Feb (c) and Aug (d). The contours on the WRF simulation are SLP anomalies (hPa) from the open ocean SLP at $115 \mathrm{E}$.

Over land, there are some noticeable differences between FNL analysis and WRF model (Figure 12). Due to the coarse resolution, FNL analysis is not able to present small-scale wind patterns over land. At $18 \mathrm{~km}$ resolution, the WRF model simulates more details on the horizontal distribution of wind speed over land. The model also simulates strong wind speeds associated with Truong Son Mountain Range (from $11.5^{\circ} \mathrm{N}$ to $19^{\circ} \mathrm{N} ; 104^{\circ} \mathrm{E}$ to $108^{\circ} \mathrm{E}$ ) with wind speed stronger than $6 \mathrm{~m} \mathrm{~s}^{-1}$ (Figures 12(c) and 12(d)) which is not seen in the FNL data (Figures 12(a) and 12 12(b)). The stronger wind is due to higher wind speed at a high elevation of the mountain and the channel effect between mountain tops (Figure 12).

The advantages of high resolution in wind speed simulation can be seen more clearly at $2 \mathrm{~km}$ horizontal resolution. WRF simulation shows much more details of wind speed distribution in comparison with those of FNL analysis (Figure 13). The FNL data only show nine values of wind speeds over the whole region, whereas WRF simulation at $2 \mathrm{~km}$ resolution presents detailed information over both ocean and inland. The effect of friction on wind speeds is visible at coastal areas of $\mathrm{Ca}$ Mau, Bac Lieu, Soc Trang, and Ben Tre provinces, where wind speeds are rapidly decreased from about 4 to $5 \mathrm{~m} \mathrm{~s}^{-1}$ over open ocean to $1-2 \mathrm{~m} \mathrm{~s}^{-1}$ at about $40 \mathrm{~km}$ inland (Figure 13, right). The relatively strong wind speeds over river regions due to less friction are also simulated in $2 \mathrm{~km}$ resolution simulation in both winter (Figure 13, top-right) and summer (Figure 13, bottomright). Those features are not seen in the FNL data (Figures 13, left). It is interesting to see that although the SV region is more affected by the southwest summer monsoon, wind speeds over the eastern coast region and $\mathrm{Ca}$ Mau are much stronger in winter (Figure 13, right-top) than in the summer (Figure 13, right-bottom). The stronger mean wind in winter in the region may be mainly due to the advection of high-momentum air in a strong wind speed region during the day as a result of the funnel effect in winter as mentioned in the above discussion (Figures 10(b) and 12(c)).

Over land at about $20 \mathrm{~km}$ from the western coast in Kien Giang and An Giang provinces, WRF-simulated wind speed 

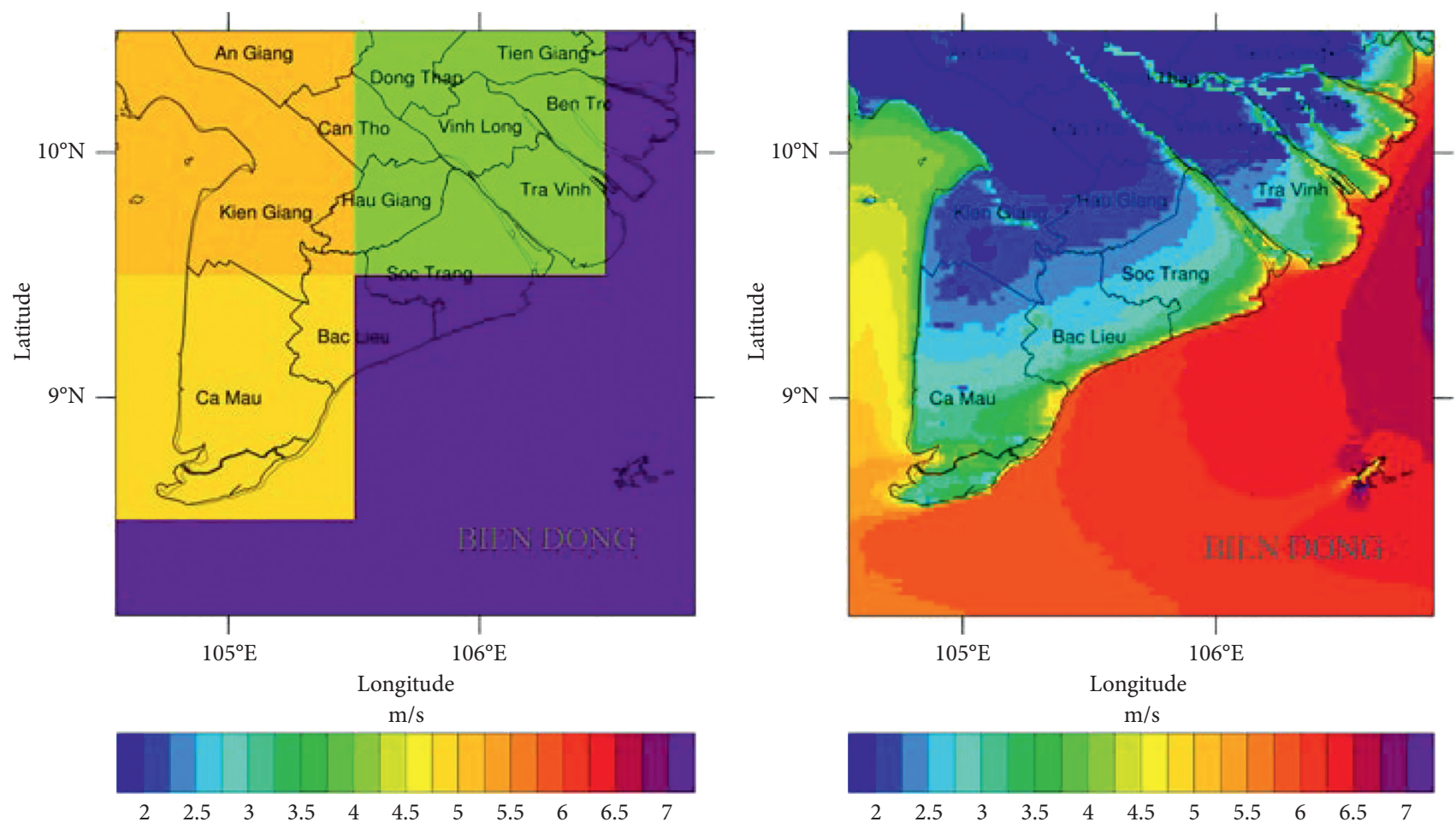

(a)

(b)

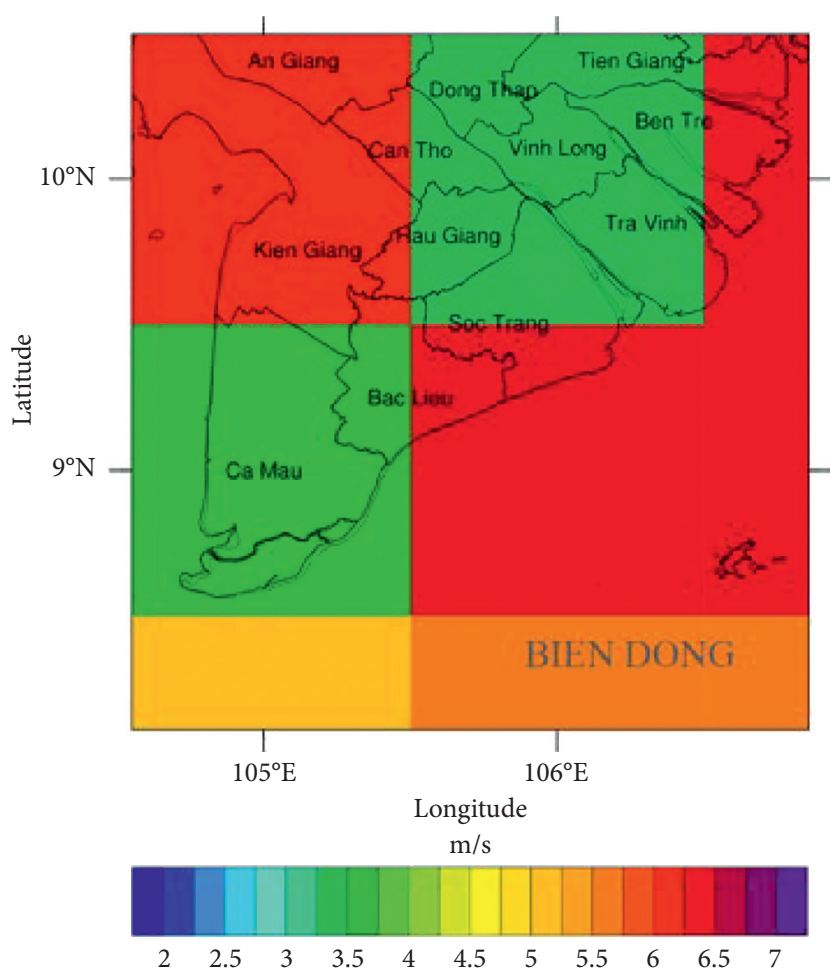

(c)

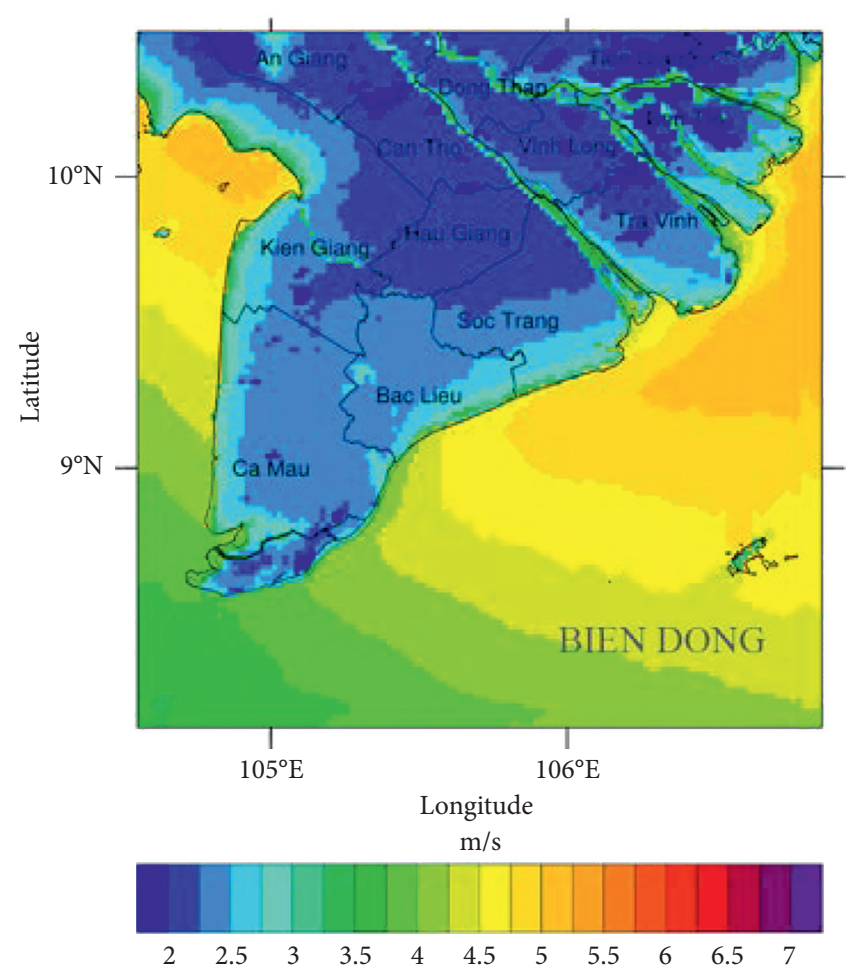

(d)

FIgURE 13: Mean wind speed at $10 \mathrm{~m}$ height from FNL data (left) and WRF model at $2 \mathrm{~km}$ resolution (right) for January (top) and July (bottom). 


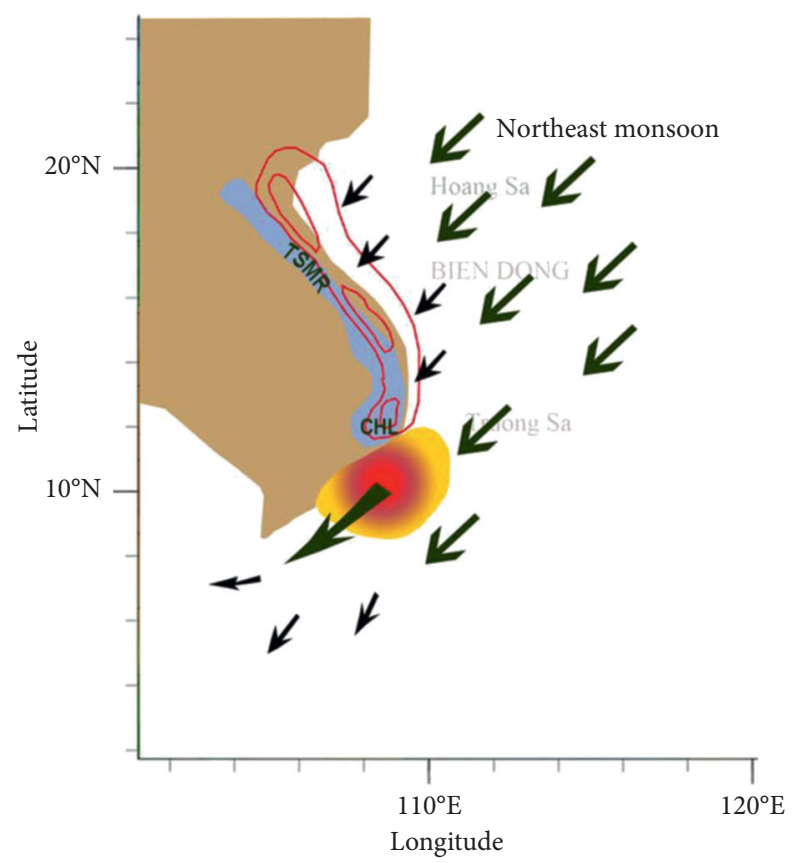

(a)

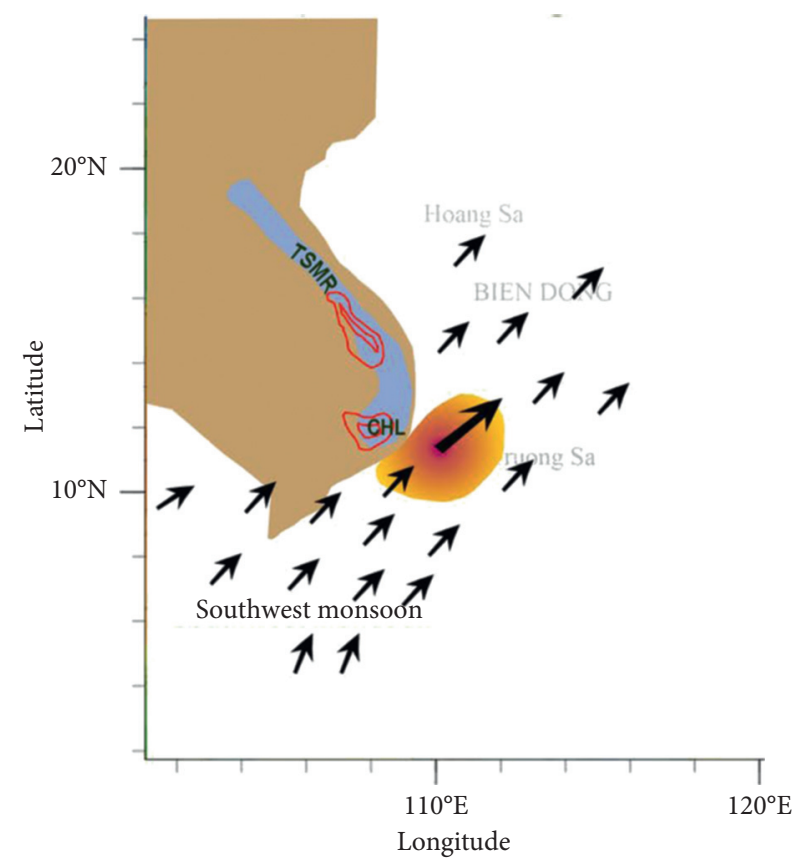

(b)

FIGURE 14: Schematic diagram of monsoon-land-ocean interaction and its effects on wind speeds over SV region for (a) winter regime and (b) summer regime. The yellow color indicates landmass. The dark-green color denotes Truong Son Mountain Range (TSMR) and Central Highlands (CHL). Red contours are pressure anomalies due to the orographic blocking effect. Black wind vectors for each wind regime with the maximum wind speed denote by the largest vectors. The color shading regions are local maximum wind speed location due to the funnel effect as a result of monsoon-land-sea interaction.

in the summer is about $1 \mathrm{~m} \mathrm{~s}^{-1}$ stronger than in winter (Figure 13, right). The stronger wind speed over the region may be due to the advection of relatively strong southwest winds flow inland in the summer daytime (Figures 10(d) and $12(\mathrm{~d}))$.

A schematic diagram of monsoon-land-sea interaction and their effects on wind speed over the SV region is shown in Figure 14. The yellow color indicates landmass. The darkgreen color denotes Truong Son Mountain Range (TSMR) and Central Highlands (CHL). Red contours are pressure anomalies due to the orographic blocking effect. Black wind vectors for each wind regime with the maximum wind speed denote the largest vectors at the maximum wind center over ocean. The color shading regions are local maximum wind speed locations due to the funnel effect as a result of monsoon-land-sea interaction. In winter, the interaction of northeast monsoon with landmass and TSMR creates a high-pressure anomaly over central Vietnam. The highpressure anomaly results in reducing wind speed over nearshore and coastal regions of central Vietnam due to the orographic blocking effect. The reducing wind speeds are presented by smaller arrows. The high-pressure anomaly is also one of the main reasons for creating a local maximum wind region over the nearshore ocean regions of SV in winter. The local maximum wind region over open ocean makes wind speeds over easterly coastal region strongest in wintertime (Figure 14(a)).

In summer (Figure 14(b)), with the southwest monsoon regime dominating, the anomaly high pressure over northern Vietnam, eastern TSMR, disappears. A highpressure anomaly with a relatively small magnitude formed over the western side of the TSMR. The location of nearshore wind maximum center moves to the north. The relatively strong wind speed in summertime over the SV region is due to the strengthening of the dominated large-scale southwest monsoon (Figure 14(b)).

\section{Summary and Discussion}

In this work, the WRF Model Version 3 was used to simulate and investigate the diurnal and annual variation of wind speeds and wind power density over the SV region. The model initial and boundary conditions are from the NCEP Final Analyses (FNL). High-resolution (2 km) WRF data of a two-year period from January 2016 to December 2017 were collected. Wind data at $20 \mathrm{~m}$ height with a time interval of one minute at Bac Lieu station for the same period were used for model bias correction and to investigate the diurnal and annual variation of wind speed in the research area.

The simulated results show that the WRF model overestimates wind speeds in the SV region. The too strong simulated wind speed may due to the WRF model itself or the fact that wind speed in FNL input is too strong, compared to observation. The too strong FNL wind speed suggested that FNL product should not be directly used for wind resource assessment and a downscale model simulation is required. To reduce the systematic bias in WRFsimulated wind speed, an empirical scheme for wind speed 
adjustment was constructed. After bias correction, the WRF model at $2 \mathrm{~km}$ resolution reasonably well simulates wind speeds over the SV region.

The adjusted wind speeds from model simulation were used to construct wind speed and wind power density maps for a wind energy assessment. The results show that both wind speed and wind power density rapidly increase with height and with decreasing distance to the coast due to reducing in effect of surface friction with height in the lower boundary layer and larger surface friction inland than that of oversea.

The results also suggest that the eastern coastal regions of SV within 10-20 km distance from the coast, including Bac Lieu, Soc Trang, Tra Vinh, and Ben Tre provinces, have the most potential to exploit wind energy. At levels below $100 \mathrm{~m}$, the wind power density in the coastal region is about $100-150 \mathrm{~W} \mathrm{~m}^{-2}$. At higher levels of $150-200 \mathrm{~m}$ above ground level, the zone of high potential wind energy of about $200-250 \mathrm{~W} \mathrm{~m}^{-2}$ can be extended to $40-50 \mathrm{~km}$ from the coast.

Wind speed is much stronger during daytime than that at night because of well vertical mixing of high-momentum air aloft to the lower boundary layer and advection of highmomentum air from ocean to inland areas. The low-level wind speed reaches its maximum at about $14 \mathrm{LT}$ to $15 \mathrm{LT}$ when the vertical momentum mixing is the most active. The high-resolution WRF model well simulates both annual and diurnal cycles of wind speeds.

Observed and simulated wind speeds show a significant annual cycle. Wind speeds over the eastern coastal region of SV are much stronger in winter than those in the summer due to stronger large-scale wind speeds in winter than those in summer and funnel effect in a condition of small surface friction over the ocean (Figure 14). The strong wind region is one of the main reasons to make observed wind speeds over the Bac Lieu region reach their annual maximum in the winter time. While funnel effect is the main mechanism for the formation of annual winter maximum in wind speed at Bac Lieu region, the maximum wind speed in August over Bac Lieu region in particular, in SV region, in general, is mainly due to the dominant relatively strong wind speed in large-scale southwest monsoon in summer.

\section{Data Availability}

WRF model input data are available at https://rda.ucar.edu/ datasets/ds083.2, and output data are large files, available per request. Bac Lieu station data can be requested at http:// www.igp-vast.vn/index.php/en.

\section{Conflicts of Interest}

The authors declare that they have no conflicts of interest.

\section{Acknowledgments}

This work was funded by the project titled "Study and Assessment Emissions and the Effects of Radioactive from Changjiang and Fangchenggang Nuclear Power Plants to Vietnam" with Project No. KC.05.07/16-20 under the National
Science and Technology Program Period 2016-2020: "Applied Research and Energy Technology Development." This research was also partially supported by the VAST.CTG.01/17-191 project, Centre for Informatics and Computing, Vietnam Academy of Science and Technology; the National Foundation for Science and Technology Development (NAFOSTED) under Project no. 105.06-2016.12 titled "A study on the role of terrain effect and dynamic forcing on mechanism for occurrence of heavy rainfall events in Vietnam by the WRF (Weather Research and Forecasting) model"; the project titled "Development of the operational system for quantitative precipitation forecasting over the Southern Vietnam and heavy rainfall nowcasting for Ho Chi Minh City", Code: KC.08.14/16-20; the FIRST-IGP Subproject (No. 16/FIRST/2A/IGP); and the VTCN.02/18-20 project. The authors would like to thank Dang Hong Nhu, Nguyen Thanh Linh, Tran Duc Tru, and Ta Huu Chinh for their comments and assistance.

\section{References}

[1] International Renewable Energy Agency, Renewable Energy Capacity Statistics 2015, International Renewable Energy Agency, Abu Dhabi, UAE, 2018, https://www.irena.org/ publications/2015/Jun/Renewable-Energy-CapacityStatistics-2015.

[2] T. V. Ramachandra and B. V. Shruthi, "Wind energy potential mapping in Karnataka, India, using GIS," Energy Conversion and Management, vol. 46, no. 9, pp. 1561-1578, 2005.

[3] P. Diaz and A. N. H. Hahmann, "South baltic wind atlas: south baltic offshore wind energy regions project roskilde: danmarks tekniske universitet, risø nationallaboratoriet for bæredygtig energi. Denmark," Forskningscenter Risoe. Risoe$R$, vol. 75, 2011.

[4] N. Duc Luong, "A critical review on potential and current status of wind energy in Vietnam," Renewable and Sustainable Energy Reviews, vol. 43, pp. 440-448, 2015.

[5] A. N. Hahmann, A. P. Diaz, and J. C. Hansen, "WRF mesoscale pre-run for the wind atlas of Mexico department of wind energy e report 2016," 2016.

[6] C. Ilkiliç, "Wind energy and assessment of wind energy potential in Turkey," Renewable and Sustainable Energy Reviews, vol. 16, pp. 1165-1173, 2012.

[7] M. R. Islam, N. A. Rahim, K. H. Solangi, and R. Saidur, "Assessing wind energy potentiality for selected sites in Malaysia," Energy Education Science and Technology Part A, vol. 29, pp. 611-626, 2011.

[8] S. Janjai, I. Masiri, W. Promsen et al., "Evaluation of wind energy potential over Thailand by using an atmospheric mesoscale model and a GIS approach," Journal of Wind Engineering and Industrial Aerodynamics, vol. 129, pp. 1-10, 2014.

[9] A. Mostafaeipour, M. Jadidi, K. Mohammadi, and A. Sedaghat, "An analysis of wind energy potential and economic evaluation in Zahedan, Iran," Renewable and Sustainable Energy Reviews, vol. 30, pp. 641-650, 2014.

[10] W. Musial, D. Heimiller, P. Beiter, G. Scott, and C. Draxl, "Offshore wind energy resource assessment for the united states," vol. 88, 2016, http://www.osti.gov/scitech Available electronically at SciTech Connect.

[11] K. Q. Nguyen, "Wind energy in Vietnam: resource assessment, development status and future implications," Energy Policy, vol. 35, no. 2, pp. 1405-1413, 2007. 
[12] F. Pimenta, W. Kempton, and R. Garvine, "Combining meteorological stations and satellite data to evaluate the offshore wind power resource of Southeastern Brazil," Renewable Energy, vol. 33, no. 11, pp. 2375-2387, 2008.

[13] D. Zhang, M. Davidson, B. Gunturu, X. Zhang, and V. J. Karplus, “An integrated assessment of China's wind energy potential," Available online at: http://globalchange. mit.edu/publication/15634, 2014.

[14] D. Carvalho, A. Rocha, M. Gómez-Gesteira, and C. Santos, “A sensitivity study of the WRF model in wind simulation for an area of high wind energy," Environmental Modelling \& Software, vol. 33, pp. 23-34, 2012.

[15] D. Carvalho, A. Rocha, M. Gómez-Gesteira, and C. Silva Santos, "WRF wind simulation and wind energy production estimates forced by different reanalyses: comparison with observed data for Portugal," Applied Energy, vol. 117, pp. 116-126, 2014.

[16] J. C. Y. Lee and J. K. Lundquist, "Evaluation of the wind farm parameterization in the Weather Research and Forecasting model (version 3.8.1) with meteorological and turbine power data," Geoscientific Model Development, vol. 10, no. 11, pp. 4229-4244, 2017.

[17] C. Mattar and D. Borvarán, "Offshore wind power simulation by using WRF in the central coast of Chile," Renewable Energy, vol. 94, pp. 22-31, 2016.

[18] P. Mohammadpour, M. H. Malakooti, and M. Satkin, "Evaluation of planetary boundary layer simulations for wind resource study in east of Iran," Renewable Energy, vol. 111, pp. 1-10, 2017.

[19] F. J. Santos-Alamillos, D. Pozo-Vázquez, J. A. Ruiz-Arias, V. Lara-Fanego, and J. Tovar-Pescador, "A methodology for evaluating the spatial variability of wind energy resources: application to assess the potential contribution of wind energy to baseload power," Renewable Energy, vol. 69, pp. 147-156, 2014.

[20] W. Yu, R. Benoit, C. Girard et al., "Wind energy simulation toolkit (west): a wind mapping system for use by the windenergy industry," Wind Engineering, vol. 30, no. 1, pp. 15-33, 2006.

[21] PMD 248, 2016: Prime Minister, “Decision no.428/qđ-ttg dated mar 21, 2016 on approving the national master plan for power development for the 2011-2020 period with the vision to 2030," (In Vietnamese), 2016.

[22] L. V. Luu, L. V. Huy, P. X. Thanh, and H. H. Son, "Investigation and assessment of wind power potentiality at phuoc Hoa (Binh Dinh)," Journal of Sciences of the Earth, vol. 28, no. 3, pp. 376-381, 2006, in Vietnamese with English abstract.

[23] Wind energy resource atlas of Southeast Asia, True Wind Solutions, LLC 2001, Wind energy resource atlas of Southeast Asia, Albany, NY, USA, 2001.

[24] A. W. S. Truepower, "Wind resource atlas of Vietnam," 2011, https://www.esmap.org/sites/esmap.org/files/MOIT_ Vietnam_Wind_Atlas_Report_18Mar2011.pdf.

[25] D. N. Nguyen and H. T. Nguyen, Climate and Climate Resources in Vietnam, Agricultural Publishing House, Hanoi Vietnam, in Vietnamese, 2004.

[26] X. T. Pham, B. Fontaine, and N. Philippon, "Onset of the summer monsoon over the southern Vietnam and its predictability," Theoretical and Applied Climatology, vol. 99, no. 1-2, pp. 105-113, 2010.

[27] C. M. Tran, Climate and General Meteorology, Hanoi National University Publishing House, Hanoi, Vietnam, (in Vietnamese), 2007.
[28] W. C. Skamarock, J. B. Klemp, J. Dudhia et al., “A description of the Advanced Research WRF version 2," National Center for Atmospheric Research Tech, vol. 88, 2005.

[29] D. Carvalho, A. Rocha, M. Gómez-Gesteira, and C. Silva Santos, "Sensitivity of the WRF model wind simulation and wind energy production estimates to planetary boundary layer parameterizations for onshore and offshore areas in the Iberian Peninsula," Applied Energy, vol. 135, pp. 234-246, 2014.

[30] C. Draxl, A. N. Hahmann, A. Peña, and G. Giebel, "Evaluating winds and vertical wind shear from Weather Research and Forecasting Model forecasts using seven planetary boundary layer schemes," Wind Energy, vol. 17, no. 1, pp. 39-55, 2014.

[31] J. Dudhia, "Numerical study of convection observed during the winter monsoon experiment using a mesoscale two-dimensional model," Journal of the Atmospheric Sciences, vol. 46, no. 20, pp. 3077-3107, 1989.

[32] J. S. Kain and J. M. Fritsch, "Convective parameterization for mesoscale models: the kain-fritsch scheme," The Representation of Cumulus Convection in Numerical Models, vol. 24, pp. 165-170, 1993.

[33] E. J. Mlawer, S. J. Taubman, P. D. Brown, M. J. Iacono, and S. A. Clough, "Radiative transfer for inhomogeneous atmospheres: RRTM, a validated correlated-k Model for the longwave," Journal of Geophysical Research: Atmospheres, vol. 102, no. 14, pp. 16663-16682, 1997.

[34] G. Thompson, R. M. Rasmussen, R. M. Rasmussen, and W. D. Hall, "Explicit forecasts of winter precipitation using an improved bulk microphysics scheme. Part II: implementation of a new snow parameterization," Monthly Weather Review, vol. 136, no. 12, pp. 5095-5115, 2008.

[35] A. Altunkaynak, T. Erdik, İ. Dabanlı, and Z. Şen, "Theoretical derivation of wind power probability distribution function and applications," Applied Energy, vol. 92, pp. 809-814, 2012.

[36] M. Jamil, S. Parsa, and M. Majidi, "Wind power statistics and evaluation of wind energy density," Renewable Energy, vol. 6, no. 5, pp. 623-628, 1995.

[37] T. P. Chang, "Performance comparison of six numerical methods in estimating Weibull parameters for wind energy application," Applied Energy, vol. 88, no. 1, pp. 272-282, 2011.

[38] C. G. Justus, W. R. Hargraves, A. Mikhail, and D. Graber, "Methods for estimating wind speed frequency distributions," Journal of Applied Meteorology, vol. 17, no. 3, pp. 350-353, 1978.

[39] C. Rocha, R. C. De Sousa, C. F. De Andrade, and M. E. V. Da Silva, "Comparison of seven numerical methods for determining Weibull parameters for wind energy generation in the northeast region of Brazil," Applied Energy, vol. 89, pp. 395-400, 2012. 